\title{
Makedonya Türkçe çocuk edebiyatına katkıları bağlamında Necati Zekeriya (çocuk hikâyeleri çocuk şiirleri ve çocuk edebiyatı antolojileri)
}

Mustafa Said KIYMAZ1

APA: Kıymaz, M. S. (2020). Makedonya Türkçe çocuk edebiyatına katkıları bağlamında Necati Zekeriya (çocuk hikâyeleri çocuk şiirleri ve çocuk edebiyatı antolojileri). RumeliDE Dil ve Edebiyat Araştırmaları Dergisi, (20), 242-266. DOI: 10.29000/rumelide.791417.

$\ddot{O} \mathbf{z}$

Bu çalışmada Eski Yugoslavya sınırları içerisinde yer alan, günümüzde ise Kuzey Makedonya olarak adlandırılan ülkede doğan ve ömrünün büyük bir kısmını burada geçiren şair, yazar, gazeteci ve yayıncı Necati Zekeriya'nın çocuk edebiyatı çalışmaları üzerinde durulmaktadır. Balkanlar'daki Türkçe edebiyattan bahsedilirken ismi ilk anılan sanatçılardan olan Necati Zekeriya hakkında kapsamlı bir çalışma henüz yapılmamıştır. Verimli bir yazar olan Necati Zekeriya çocuk edebiyatına sadık kalan ve asıl uğraşını bu alanda yoğunlaştıran bir sanatçıdır. Bu çalışmada onun çocuk edebiyatı alanında yaptığı çalışmalar ayrı başlıklar altında incelenmiştir. Eserlerinden hareketle yazarın çocuğa ve çocukluğa dair düşünceleri devrin şartları da dikkate alınarak değerlendirilmiştir. Türkiye dışında Türkiye Türkçesi ile yapılan tek edebiyat konumunda olan Makedonya Türk edebiyatının bu önemli temsilcisinin, en azından bir yönü bu çalışma aracılığı ile bilinir kılınmaya çalışılacaktır. Çalışma üç bölümden oluşmaktadır. Giriş bölümünde, Türklerin bölgeye gelişleri ve ortaya çıkışından günümüze uzanan çizgide Makedonya'da Türkçe çocuk edebiyatının gelişimi anlatılmıştır. İkinci bölümde ise gerek yazarın kendi ifadeleri gerekse de onun hakkında yazılanlardan hareketle sanatçının hayatı ve sanatı incelenmiştir. Son bölümde ise sanatçının çocuk edebiyatı kapsamına giren antolojileri, hikâyeleri ve şiirleri üzerinde durulmuştur. Sonuç bölümünde Necati Zekeriya'yı ve onun çocuk edebiyatı çalışmalarını tanımanın Makedonya'daki ve Türkiye'deki Türk edebiyatları açısından önemi vurgulanmıştır.

Anahtar kelimeler: Türkçe öğretimi, çocuk edebiyatı, Necati Zekeriya, Makedonya

\section{Necati Zekeriya (children's stories, children's poems and children's literature anthologies) in the context of their contribution to Macedonian Turkish children's literature}

\begin{abstract}
This study focuses on children's literature studies of the poet, writer, journalist and publisher Necati Zekeriya, who is located within the borders of the former Yugoslavia, now called North Macedonia, and spent most of his life here. While talking about Turkish literature in the Balkans, no neat work has been done on Necati Zekeriya, one of the first mentioned artists. Necati Zekeriya, who is an efficient writer, is an artist who stays true to children's literature and concentrates his main work in this field. In this study, his studies in the field of children's literature are examined under separate titles. Based on his works, the writer's thoughts on the child and childhood and the conditions of the transfer were also evaluated. Turkey made outside Turkey with the Turkish literature in a single
\end{abstract}

Dr. Öğr. Üyesi, Adlyaman Üniversitesi, Eğitim Fakültesi, Türkçe ve Sosyal Bilimler Eğitimi Bölümü, Türkçe Eğitimi ABD (Adiyaman, Türkiye) mustafasaid_65@hotmail.com, ORCID ID: oooo-0003-3821-5499 [Makale kaylt tarihi: 24.05.2020-kabul tarihi: 20.09.2020; DOI: 10.29000/rumelide.791417]

Address

Kırklareli University, Faculty of Arts and Sciences, Department of Turkish Language and Literature, Kayalı Campus-Kırklareli/TURKEY e-mail: editor@rumelide.com 


\begin{abstract}
location of this important representatives of the Macedonian Turkish literature, at least in one direction will try to make known through this work. There are three main topics in the study. Under the title of introduction, the development of Turkish children's literature in Macedonia has been tried to be taken in line with the arrival of Turks to the region and their emergence. Later on, the artist's life and art were examined based on the writer's own expressions and what was written about him. Finally, the anthologies, stories and poems of the artist, which are within the scope of children's literature, are emphasized. In the conclusion section Necati Zekeriya and children's literature in recognition of his work in Macedonia and Turkey it has been focused on the importance of Turkish literature.
\end{abstract}

Keywords: Turkish teaching, children's literature, Necati Zekeriya, Macedonia

\title{
1. Giriș
}

Modern anlamda çocuk edebiyatının başlangıcının ilk işaretleri Sanayi Devrimi sonrasındaki sosyal hayattaki gelişmelerle başlamıştır. Çocukluğun insan ömründe ayrı ve özel bir zaman dilimi olduğunun anlaşılmaya başlanması, çocukların yetişkinlerden ayrı ihtiyaçları olduğunun kabul edilmesini de beraberinde getirmiştir. Osmanlı'da ise Tanzimat döneminde önem kazanan çocuk ve eğitim anlayışının topluma tümüyle hâkim olduğunu söylemek mümkün değildir. Bir aydın hareketi olarak başlayan ve kimi zaman yönetim tarafından destek gören bu anlayış; kimi zaman da yönetimin ve toplumun tepkileriyle karşılaşmıştır (Neydim, 1998). Tanzimat döneminden itibaren ilk ürünlerini vermeye başlayan Türk çocuk edebiyatı, Nuhbetü'l Etfal (1859) adlı alfabe kitabındaki kısa öyküler ve Mümeyyiz (1869) adlı çocuk gazetesi ile ilerlemesini sürdürmüştür. Bu iki örnekten de anlaşlacağı üzere çocuk edebiyatı, çocuk eğitimi ve ana dil öğretimi ile birlikte düşünülmektedir. Cumhuriyet'e kadar siyasi değişikliklerden de etkilenerek gelen bu edebiyat kolu, Cumhuriyet'in ilanı ve sonrasındaki alfabe değişikliği sonrasında yeni bir bakış açısı ile ele alınmıştır. Özellikle çocuklardan başlayarak okuryazar ve ana dilinin özelliklerine hâkim bir nesil oluşturma çabası kapsamında, çocuk edebiyatı ürünlerinin işlevsel olarak kullanıldığı görülmektedir. Çocuk Sesi ve Yavrutürk gibi uzun ömürlü dergiler, içeriklerindeki farklı metinlerle bir okul görevi görmüşlerdir.

Dil öğretimi, gerek ana dil gerekse de yabancı dil olarak büyük ölçüde metinler üzerinden yapılmaktadır. Seviyesine uygun yazılmış ve estetik değer taşıyan metinlerle karşılaşan çocuklar, dil gelişimi anlamında daha hızlı bir gelişim gösterebilmektedirler. Türkiye'nin sınırları dışında kalan; fakat Türklerin yaşamaya devam ettiği yerlerde Türkçe öğretiminin temel sıkıntısı her zaman kitap olmuştur. Özellikle öğrencilerin ders kitapları yanında okuma materyali olarak çocuk kitapları, Türkçenin öğretimi açısından vazgeçilmez değerdedir. Türkiye dışında Türkiye Türkçesi ile zengin bir edebiyat birikimi Makedonya sınırları içerisinde yaşamaktadır. Esasında burada yaşayan insanlar da iskân politikaları çerçevesinde zamanında Anadolu'dan gelmişlerdir. Balkan coğrafyası, zamanındaki nitelikli insan gücü ile Cumhuriyet’in kurucu kadroları başta olmak üzere birçok edebiyat ve sanat insanını bünyesinden çıkarmıştır. Bu çalışmada aynı zamanda bir öğretmen olan Necati Zekeriya'nın Üsküp merkezli olmak üzere Makedonya'da Türkçenin Türk çocukları tarafından ana dilleri olarak öğrenilmesine sunduğu katkılar çocuk edebiyatı çalışmaları üzerinden değerlendirilmiştir.

\subsection{Makedonya ve Türkler}

Türklerin Makedonya olarak anılan coğrafyaya gelişleri çok eskidir. Bilinenin aksine Türklerin bu topraklara gelişleri Osmanlı zamanından daha öncelere tarihlenmektedir. Hamzaoğlu (2010) konuyla 
Necati Zekeriya (children's stories, children's poems and children's literature anthologies) in the context of their contribution to Macedonian Turkish children's literature / M. S. Kiymaz (pp. 242-266)

ilgili çalışmasında Türklerin Balkan topraklarına gelişini çok eskilere tarihlemektedir. Ona göre 372 yllında Hun Türkleri ile başlayan Makedonya Türklüğü, üç devreden oluşmaktadır:

1. Osmanlı Öncesi Makedonya Türklüğü (372-1370)

2. Osmanlı Dönemi Makedonya Türklügü (1371-1912)

\section{Osmanlı Sonrası Makedonya Türklüğü (1912-Günümüz)}

Birinci devre olarak görülen döneme ait Türk izlerini mimari eserlerden ziyade bazı yer, bölge ve akarsu isimlerinde bulmak mümkündür. Gostivar, Kumanova, Veles, Sarakino, Şar, Peçentsi, Peçenitsi gibi şehir ve yer adları; Vardar, Radika ve Drim gibi akarsu isimlerinin yanında Vardarinka, Devena ve Sarakina gibi kadın adlarında da anılan izler söz konusudur (Hamzaoğlu, 2010). Müslüman Anadolu Türklerini Makedonya'ya gelişleri Sarı Saltuk gibi kolonizatör Türk dervişleri ile 13. yüzyılda başlamıştır. Osmanlı hâkimiyeti ise 1371 Meriç Zaferi ile olmuştur. Fetihle birlikte Anadolu'nun Aydın, Konya, Karaman ve Maraş gibi yerlerinden bu bölgeye iskân edilen insanlar eliyle Makedonya kısa süre içinde bir Türk yurdu olmuştur (Turan, 1996).

Yaklaşık 500 sene Osmanlı idaresinde kalan Balkan toprakları, yalnız siyasi olarak değil; sosyal ve kültürel açılardan da değişime uğramıştır. Osmanlı Devleti’nin Balkanlara yaptığı yatırımlar ve nüfus hareketleri göz önüne alındığında, Türklerin bu toprakları her yönüyle sahiplenip, geliştirmeye çalıştıkları görülmektedir. Uzun bir zaman dilimini kapsayan bu devrede, Balkan şehirleri içerisinde Üsküp, eyalet merkezi konumuyla birçok şairin yetiştiği bir kültür şehri özelliği göstermektedir. Birlikte yaşanılan farklı ulus ve topluluklara dil ve inanç serbestisi tanınması, Türk kültürü ile Balkan kültürleri arasında yoğun bir alışverişi de beraberinde getirmiştir. Yukarıda bahsedilen bu değişimlerin getirdiği sonuçlara bugün hepsi ayrı devletler olan toplulukların dillerinde ve kültürlerinde rastlamak mümkündür.

1912 yılında Osmanlı Devleti’nin bozgun halinde bölgeden çekilmesiyle, Sırplar Üsküp ve çevresini kontrol altına almışlardır. Bölgede yaşayan Türklerden gidebilenler İstanbul'a kaçmış; kalanlar ise Sırplar tarafından amansız işkencelere maruz bırakılmıştır. II. Balkan Savaşı ve sonrasında I. Dünya Savaşı, Makedonya Türklerini daha da ağır şartlar içinde yaşamaya mecbur bırakmıştır. 1918'de, savaşın bitimiyle Sırp-Hırvat-Sloven Krallığı kurulmuştur. Birinci Yugoslavya olarak da bilinen bu devlette Türkler kendilerini ifade için geniş imkânlardan mahrum kalmışlardır. Önde gelen Türk aydın, eğitimci ve yöneticilerin büyük kısmı bozgunla birlikte bölgeyi terk ettikleri için geniş halk tabakalarına, ağır günlerde el uzatıp yardımcı olacak kişiler kalmamıştır (Kaya, 1999). Anılan bu dönemde Türk çocukları Sırp okullarına gitmeye zorlanmıştır. Müslüman halkın eğitimle ilgili taleplerinden en önemlisi dini derslerin Müslüman hocalar tarafından verilmesi ve Müslüman çocuklarının Ortodokslukla ilgili dersleri almaması ve dini törenlere katılmaması olarak belirmiştir. Kendi okullarını açmak isteyen Türk halka bu izin verilmediği gibi Türkçe alfabe yasaklanmış ve daha önceden okul olarak hizmet veren binalar askeri kullanıma tahsis edilmiştir (Hasan, 1998a).

II. Dünya Savaşı yıllarında Hitler liderliğindeki Almanya tarafından işgal edilen Makedonya, daha sonra İtalyan ve Arnavutlara bırakılmıştır. Gostivar'da Arnavutçayı zorunlu eğitim dili haline getiren İtalyanlar, başta Abdülhakim Hikmet Doğan olmak üzere önde gelen Türkçe öğretmenlerini Arnavutça ders vermeye ve bu dilin alfabe kitaplarını yazmaya zorlamışlardır (Tufan, 1998) Türkçe birçok eser veren bu değerli ismin, Arnavutlar tarafından kendi milletlerine mensup gösterilmeye çalışılması da bu 
alfabe kitabı ile ilgilidir. Tufan (1998: 376) bu durumu "küçük milletin büyük kompleksi" olarak açıklamaktadır. II. Dünya Savaşı esnasında Makedonya'da yaşanan sıkıntılı zamanlarda en çok mağdur olan topluluk Hamzaoğlu (2010: 287)'na göre Türklerdir. Makedonya’nın batı kesimini işgal eden İtalya'nın yönetme yetkisini Arnavutlara vermesiyle birlikte, nüfusun çoğunluğunu oluşturan Türklerin bütün hak ve hürriyetleri engellenmiştir. Türkçe okulların açılmasına izin verilmemiştir. Türkler nüfus kayıtlarında Arnavut olarak gösterilmiştir. Türk soyadlarına “-i” eki getirilmiştir. 1944 yılında, II. Dünya Savaşı'nın sonlarına doğru Tito tarafından kurulan Yugoslavya Sosyalist Federe Cumhuriyeti ile birlikte Türkler görece olarak bazı hakları elde etmişlerdir. Bu durum Türk nüfusun, vatanları olarak bildikleri toprakları savunma amacı ile savaşa katılmaları ve kanlarını dökmeleri sonucu gerçekleşmiştir. Bu yeni federe devleti oluşturan 6 cumhuriyetten biri olan Makedonya'nın anayasasında bu durum "Makedonya, Makedon, Arnavut ve Türklerin devletidir.” ibaresi ile tescillenmiştir. Bununla birlikte tam anlamiyla bir serbestlikten de bahsedilemez. II. Dünya Savaşı sonrasında mevcut yönetim, bölgedeki Türk varlığını yok sayarak Debre, Resne, Radoviş, Üsküp gibi bölgelerde ve bunlara bağlı köylerdeki Türklerin Türk olmadıkları iddiasında bulunmuştur. Bu arada bazı siyasi gelişmelerin de etkisiyle Arnavutlar da Türkleri ‘Türkleşmiş Arnavutlar' olarak göstermeye çalışmışlardır (Çayırlı, 2015: 146).

Yugoslavya Devleti’nin temelinin atıldı̆̆ı yıllarda anılması gereken, çoğu öğretmen ve aydın kişilerden oluşan bir topluluk bulunmaktadır. Yücel Teşkilatı olarak bilinen bu topluluk, bölgede yaşayan Türklerin kültürel açıdan haklarını savunmak amacıyla kurulan gizli bir teşkilattır. Makedonya'da henüz savaş tamamen bitmeden 23 Aralık 1944'te çımaya başlayan Birlik gazetesi de ilk olarak bu topluluk üyeleri tarafından çıkarılmıştır. 1980 yılında Tito'nun ölümü sonrasında sarsılan ve sükûnetin bir türlü sağlanamadığı Yugoslavya Federe Devleti dağılmıştır. Art arda bağımsızlıklarını ilan eden devletlere 1991 yılında Makedonya Cumhuriyeti de bağımsızlığını duyurarak katılmıştır. Bu yeni devletin vatandaşı olarak Türkler, milli kimliklerini koruma çabalarına devam etmektedirler.

\subsection{Makedonya'da Türk çocuk edebiyatının ortaya çıkışı}

Makedonya ve özellikle Üsküp bölgesinde çocuk edebiyatına ilişkin ilk örneklere dair bilgiyi Necati Zekeriya vermektedir. Ona göre bazı şiir parçaları bu edebiyatın ilk örnekleri sayılmalıdır. Verdiği bir röportajda (Taşgetiren, 1984: 20) Makedonya'da çocuk şiirinin geçmişini anlatırken Üsküplü Şeyh Saadettin İbrahim (1872-1936) ismini anmaktadır. Onun “Ey Vatanın Öz Kızı” adlı şiirinin estetik, sanat değeri, biçim, dil ve muhteva olarak harika bir şiir olduğunu vurgulamakta ve folklordan yararlandığını söylemektedir. Yine Zekeriya (1985) Çiğdem adlı şiir antolojisinin ön söz bölümünde özellikle iki dünya savaşı arasında ve Halk Kurtuluş Savaşı (1941-44) zamanında çocuk şiirleri yazıldığını tahmin etmekte; fakat o devirde Türkçe dergi ve gazeteler olmadı̆̆ için bu şiirlerin derlenemediğini dile getirmektedir. 1912 yılında Osmanlı'dan ayrılana kadar, Makedonya sınırları içinde gelişen çocuk edebiyatının anayurt Türkiye'deki çocuk edebiyatıyla aynı karakterde ve aynı çizgide geliştiğini görülmektedir. 1911'de yayımlanan Çocuklara Mahsus Küçük Şürler adlı eseri ile Sabri Cemil, Üsküp’te ve İstanbul'da çeşitli kitaplar yayımlamıştır (Hasan, 1998b). Birinci Yugoslavya Devleti olarak da bilinen SHS (Sırp-HırvatSloven) Krallığı (1918-1944) zamanında Türkçe ile ilgili sadece belli süreli yayınların varlığı bilinmektedir. Bu yayınların tam anlamıyla Türkler tarafından çıkarıldığını söylemek mümkün değildir. Kaya (1999) ilgili yazısında, bu dönemdeki süreli yayınların sahipleri olarak Sırpları işaret etmektedir. İkinci Dünya Savaşı sonrasında Yugoslavya'nın kurulmasıyla birlikte, bu devletin yöneticisi Tito tarafından bu ülke sınırları içerisinde yaşayan farklı etnik kökenden gelen insanlara bazı haklar verilmiştir. Bunlar arasında ana dilde eğitim, gazete, dergi ve radyo yayınları sayılabilir. Yugoslavya'yı oluşturan tüm milletlerin ortak bir çatı altında eserler vermesi ve bu eserlerden nitelikli bulunanların çevirilerinin yapılması bu çabanın bir sonucudur. 
Necati Zekeriya (children's stories, children's poems and children's literature anthologies) in the context of their contribution to Macedonian Turkish children's literature / M. S. Kiymaz (pp. 242-266)

Makedonya Türkçe çocuk edebiyatı sahasında eser veren sanatçılar birden fazla sıfata sahip olmalarıyla dikkat çekmektedirler. Bu isimler hem yazar hem şair, yerine göre öğretmen, siyasetçi, radyo programcısı, yayın sorumlusu gibi işleri bir arada yürütmüşlerdir. Birçoğunun yolu Tefeyyüz adlı okuldan; öğretmen, idareci ya da ders kitabı yazarı olarak geçmiştir. Çelebi (2015)'ye göre, Makedonya Türk çocuk edebiyatı siyasi ve sosyal karışıklıklar nedeniyle oldukça geç bir dönemde başlamıştır. Osmanlı dönemi Türk edebiyatından ayrılmasından sonra otuz yıllık fetret dönemi yaşayan Makedonya Türk edebiyatı 1944'ten başlayarak yeniden canlanmıştır. Makedonya'da gelişen Türkçe çocuk edebiyatında, Üsküp’te yayımlanan ve Türklerin sesi olarak bilinen Birlik gazetesi öncü bir konumdadır. 54 yıl aralıksız çıkan Birlik gazetesi bir manada Makedonya Türklerinin alfabesi, okuma kitabı, sesi ve sicili olmuştur (İslam, 2001: 57).

Makedonya'da oluşan Türkçe edebiyat, başlangıçta çocuk edebiyatı ile doğmuştur. İleride farklı türlerde kalem oynatan çoğu sanatçı, ilk eserlerini çocuklara yönelik olarak kaleme almıştır. Bu durumun oluşmasında Yugoslavya devletinin siyasi ve sosyal yapısının etkili olduğu söylenebilir; çünkü bu yapıda çocuklar rejimin ilerideki teminatı olarak görülmekte ve onlara verilecek eğitimin ileride devlet ve toplum yapısının devamı için hayati önemde olduğu anlayışı ön plandadır. Bu kanıyı destekleyen bir görüşe göre ise sosyalist kültürde çocuk, eğitilmeye muhtaç bir nesne olarak görülmekte ve ancak çocukluklarında iyi eğitilen insanların sistem açısından bir güvence teşkil edeceği düşünülmektedir (İsen, İsen ve Kireççi, 2008). Farklı etnik kökenden gelen insanların oluşturduğu Yugoslavya Federe Devleti’nde Tito'nun "Birlik ve beraberliğinizi gözbebekleriniz gibi koruyunuz" sözü okulların duvarlarına yazılmıştır (Füruzan, 2018). Başta Rusya olmak üzere Azerbaycan ve diğer eski Sovyet ülkelerinde olduğu gibi sosyalist Yugoslavya'da da Pioner denilen ve çocuklardan oluşan toplulukların mevcudiyeti anılan bu durumu desteklemektedir. Gürel ve Gürel (2010: 27)'e göre Makedonya Türk edebiyatının sanatç̧larının Tito Yugoslavya'sında ilk başta çocuklar için edebiyata yoğunlaşmaları, 2. Dünya Savaşı'nın ardından muhteşem mazisinden kopuk bir yeni yapılanmanın ve göçlerle de zayıflatılmış, içine kapanan durumunu yaşamış, sosyal ve siyasi şartların da getirdiği zaruretler dâhilinde açıklanmalıdır. Makedonya Türklerinde neden öğretmen yazarlar eliyle oluşturulan çocuk edebiyatının önde olduğuna dair bir başka açılamayı Hayber (2008: 11) yapmaktadır:

\begin{abstract}
“Tito Yugoslavyası döneminde Türk okullarının açılması, Üsküp’te Türkçe gazete ve Türkçe radyo yayınlarının başlaması ve benzeri kurumların faaliyete geçmesi, geniş bir aydın kadrosuna ihtiyaç olduğunu ortaya koydu. Elli yıla yakın bir zamandan beri aralıksız sürüp gelen felaketler zinciri, kimseyi bırakmamıştı. Okuma yazma bilen kimselerin bile büyük aydın olarak saygı gördüğü ve arandı̆̆ı bir dönem başladı. Onun için Makedonya Türklerinin edebiyatının ilk devresinde görülen isimlerin hemen hepsi öğretmen ve gazeteci olarak karşımıza çıkarlar. Çoğu, şair ve yazarlığa sanattan çok eğitim ve öğretimde duyulan ihtiyacı karşılamak için başlamıştı. Böyle önemli bir ihtiyaçla başlayan edebiyat, genel okuyucudan önce, eğitim öğretim gören kimselerin varlığını dikkate almak zorunda kaldı."
\end{abstract}

Kendisi de Makedonya'da yaşamış Türk çocuk edebiyatı yazarlarından olan Ali (1995), Makedonya'daki Türkçe çocuk edebiyatını üç dönemde değerlendirmiştir:

1. Halk Kurtuluş Savaşı öncesi gelişen çocuk edebiyatı (1944 Öncesi)

2. Halk Kurtuluş Savaşı sonrası gelişen çocuk edebiyatı (1944-1950)

3. Birlik gazetesinin ve çocuk dergilerinin yayımlanması ile başlayan çocuk edebiyatı (1950 Sonrası)

Birlik gazetesi bünyesinde verilen Çocuk Bahçesi ekini de yayımlayan Fahri Ali'nin, bu sınıflandırmayı yaparken Halk Kurtuluş Savaşı ile kastettiği 2. Dünya Savaşı sırasında 4 yıl boyunca Yugoslavya'da 
yaşanan ve partizan olarak anılan savaşçlarla Almanlar ve müttefikleri arasında geçen savaştır. Bu savaşta Türkler de vatanları bildikleri toprakları savunmak amacı ile savaşmışlardır. Makedonya Türkçe çocuk edebiyatı kendi geleneklerine sadık kalmakla birlikte çă̆daş Makedon ve eski Yugoslavya yazarlarından da etkilenmiştir. Bununla birlikte Türkiye'deki Türk edebiyatından da beslenmiştir. Birlik gazetesinin koleksiyonlarına göz gezdirildiğinde Fazıl Hüsnü Dağlarca, Nazım Hikmet Ran gibi Yugoslav yönetiminin karşı çıkmayacağı düşünülen yazarların biyografileri ve eserleri zaman zaman gündeme getirilmektedir. Kurulan Türk derneklerinin edebiyat kollarının isimleri de bu durumu desteklemektedir. Makedonya Türkçe çocuk edebiyatında Birlik gazetesinin ayrı bir yeri vardır. Bu edebiyatın ilk ve en güçlü örnekleri bu gazetenin çocuk sayfalarında yer bulmuştur. Ali (1995) ilk kuşak çocuk edebiyatı yazarlarını Necati Zekeriya, Hüseyin Süleyman, Şükrü Ramo, Fahri Kaya ve İlhami Emin olarak saymakta ve Birlik'in yukarıda anılan işlevini “Bunlar ilk eserlerini çocuk edebiyatına bağlı yaptılar. Bize çocuk edebiyatını sevdirdiler. Biz onların öğrencisiyiz. Birlik çerçevesinde, Birlik’i okuyarak, Birlik’i okul olarak gördük. Bu edebiyata merak sardık, bu edebiyatı izlemeye olanak bulduk." cümleleriyle ifade etmektedir.

Ali (2008), Fahri Kaya'ya ait İlk Adımlar (1952) şiir kitabını Makedonya'da yayımlanan ilk çocuk şiirleri kitabı olarak kabul eder. Gürel ve Gürel de (2010: 26) bu görüşü desteklemektedir. Bir başka araştırmacı ise (Ali, 2008: 10) Makedonya Türk çocuk edebiyatındaki ilk çocuk hikâyesi kitabı olarak Mustafa Karahasan tarafından 1950'de yazllan Küçük Erler adlı eseri gösterir. Şükrü Ramo, Makedonya Türkleri arasında önemli bir isimdir. Uzun yıllar Birlik gazetesini yönetmiştir. Çocuklar için yazdığı eserleri şunlardır: Vatan Birdir Unutma (1958), Çelenk (1960), Hoş Geldiniz (1964), Kır Çiçeği (1969), Güzel Günler (1975), Renkli Gülüşler (1977), Alevden Yıldıza (1978), Kuş Sesi (1980), Küçük Damlalar (1984).

Mustafa Karahasan, Makedonya Türk edebiyatında ismi önde gelen yazarlardan biridir. Tiyatro ve eleştiri yazıları da yazmıştır. Çocuklar için yazdığı Türkçe eserler şunlardır: Küçük Erler (1950), Kalbimin Yaşları (1957), Yedi Başlı Dev (1973), Arkadaşlar (1965). Öğretmen kökenli bir diğer çocuk edebiyatı yazarı Fahri Kaya'dır. Birçok üst düzey bürokratik görevin yanında uzun yıllar Birlik gazetesi ve Sesler dergisinde de yöneticilik yapmıştır. Makedonya'daki Türk çocuk edebiyatı tarihi açısından yazdığı değerlendirme kitapları önemlidir. Çocuklar için yazdığı kitaplar şunlardır: İlk Adımlar (1952), Köyden Sesler (1958) Hoşça Kalın (1967), Güle Güle (1978), Çocuk Rüyaları (1991), Küçük Hanım (1997). Ayrıca çocuk edebiyatı antolojileri de vardır. Recep Murat Bugariç, çocuk edebiyatı alanında yayımladığı hikâyeleriyle tanınmaktadır. Uzun süre öğretmenlik ve okul idareciliği yapmıştır. Eserleri şunlardır: Üç Palto (1974) Küçük Adam (1982), Sigara (1983) Loto (1988) Öyküler (1992). Enver Tuzcu, Nusret Dişo Ülkü, Avni Engüllü Mustafa Kıratll, Suat Engüllü, Sabit Yusuf, Fahri Ali gibi isimler de Makedonya'da Türk çocuk edebiyatına katkı sağlayan isimler arasında sayılmaktadır.

Yukarıda isimleri anılan yazar ve şairlerin tümünün yolu, kısa süreli de olsa öğretmenlikten geçmiştir. $\mathrm{Bu}$ durum sadece Makedonya'ya has değildir. Diğer Balkan ülkelerindeki Türk azınlık yazar ve şairlerinde de durum yaklaşık olarak böyledir. Bu Türk öğretmenler ülkelerindeki bütün entelektüel faaliyetleri sırtlarında taşımışlardır (İsen, İsen ve Kireççi, 2008). Özcan (2015: 46)'a göre, İkinci Dünya Savaşı sonrası Makedonya Türklerinin edebiyatında çocuklara yönelik eserlerin fazlalığı tesadüf değildir. Tam aksine, bu durum bir geçmişe/geleneğe dayanmaktadır. Osmanlı Devleti’nin son zamanlarındaki idealist eğitimcilerin, aydınların üzerinde durduğu, çocuğu en güzel şekilde yetiştirme çabası 1944’ten itibaren Türkçenin tekrar eğitim dili olmasıyla o günün idealist öğretmenleri tarafından kaldığı yerden ve dönemin şartlarına uygun biçimde devam ettirilmiştir. 
Necati Zekeriya (children's stories, children's poems and children's literature anthologies) in the context of their contribution to Macedonian Turkish children's literature / M. S. Kiymaz (pp. 242-266)

\section{Necati Zekeriya'nın hayatı ve sanat anlayışı}

Necati Zekeriya 11 Kasım 1928 tarihinde Üsküp’te doğmuştur. İlk olarak Arap bir hocadan dersler aldığı bilinmektedir. Bu bilgiyi sanatçı bizzat kendisi vermektedir. Daha sonra ise Sırpça eğitim veren Krallık Yugoslavya Devlet İlkokuluna kaydolmuştur. İkinci Dünya Savaşının başlaması ile eğitimi yarıda kalmıştır. Savaş devam ederken ailesi ile birlikte Üsküp’te kalmaya devam etmiştir (Mercan, 2002). Mahmut Demir Kıratlı'nın yazar hakkında verdiği bilgilere göre, savaş yıllarında kahveci çırağı, ayakkabıcı, manifaktür çırağı olarak çalışmıştır. Lise tahsilini ancak savaştan sonra Türk öğretmenler için açılan kurslarda tamamlayabilen sanatçı, 1947-48 yıllarında İrfan Okulu'nda bir yıl öğretmenlik yapmıştır. Daha sonra ise Felsefe Fakültesinde bir süre yükseköğrenim görmüştür (Zekeriya, 1953a). Necati Zekeriya'nın yetiştiği aile dinine ve milli geleneklere, örf ve adetlere saygılı insanlardan oluşmaktadır. Babası Türk halk türkülerini icra eden ve keman çalan bir müzisyen, annesi ise ninelerinden duyduğu halk hikâye ve masallarını çok iyi bilen ve anlatan Kumanovalı bir avukattır (Kaya, 2009). Savaşlar, işgaller ve göçler sebebiyle düzenli bir eğitim alma imkânı bulamayan Necati Zekeriya'nın bir yazar olarak kendini geliştirmesindeki ilk basamak anne ve babasından aldığı zengin Türk kültürüdür. Özellikle Türk halk edebiyatının Rumeli coğrafyasındaki türkülerini babasından, hikâye ve masallarını da annesinden dinlemesi Türkçenin zenginliklerini ve inceliklerini daha küçük yaşlarda fark etmesini sağlamıştır.

Necati Zekeriya hakkında, onunla aynı ortamda çalışan Fahri Kaya'nın tespitleri dikkat çekicidir. Kaya’ya göre Necati Zekeriya, Makedonya Türklerinin edebiyatında hala derli toplu anlatılamamış, yorumlanmamış, önemli, büyük ve değerli bir yere sahiptir.

“O sadece edebiyat hazinemizi zenginleştiren bir yazar değil, aynı zamanda başarılı bir gazeteci, iyi bir eğitmen, becerikli bir yayıncı, kültür alanında deneyimli bir örgütleyiciydi. Çok önemli bir özelliği de, düşünce üreten bir kişi olmasıydı. Sözün kısası, her zaman iyi bir şey yapmayı, güzel bir eser meydana getirmeyi, başta ortamı için yararlı bir eylemde bulunmayı amaçlayan, seyrek aydınlarımızdan biriydi." (Kaya, 2009).

Necati Zekeriya, İsen'e göre (2013: 209) Yugoslavya'da sosyalist yönetimin her toplumun kendi ana dilinde fakat sistemin beklentileri doğrultusunda yeni bir edebiyat oluşturma gayreti çerçevesinde var edilmeye çalışılan Türk yazarları arasında Türkçeyi doğru ve güzel kullanan az sayıdaki yazardan biridir.

Ömrünün son yıllarında kalbiyle alakalı rahatsızlıklar Necati Zekeriya'yı zorlamaya başlamıştır. Sanatçı, 1986 yılında Ohri'de kalp hastalıkları hastanesinde yatışlı olarak tedavi görüp taburcu olmuştur. Nükseden rahatsızlık sonucu, enfarktüs sebebiyle 1988 yllının Haziran ayında Voyvodina özerk bölgesinde, Novi Sad yakınlarındaki Sremska Kamenitsa'daki ünlü kalp hastalıkları hastanesinin ameliyat masasında dünyaya gözlerini yummuştur. Vefatının ardından Varlık dergisinde çıkan bir yazısında Tarık Dursun K. (1992) Necati Zekeriya'yı "Ihlamurlar Kâş̧ifi” olarak tanımlamaktadır. Bu tanım onun hayata bakış ve algılayışındaki hassasiyeti anlatmak için kullanılmıştır. Tarık Dursun'a göre Necati Zekeriya bulduğu her firsatta şiir okuyan, şiiri hayatının başköşesine koyan bir sanatçıdır. Söz konusu yazıdan Necati Zekeriya'nın Üsküp’ün her bir köşesini, Vardar nehrini sevdiğini anlamak mümkündür. Ayrıca istemediği halde Üsküp’ten ayrılışı Necati Zekeriya'yı çok etkilemiştir. Kendisi de çocuklar için yazan ve sağlığında Necati Zekeriya ile vakit geçirme imkânı bulan Beksaç (2014) onu Balkan Türk çocuk edebiyatının özellikle de çocuk öyküsünün sönmeyen yıldızı ve Türk edebiyatının Avrupa hatta dünya çapında bir çocuk hikâyecisi olarak anmaktadır.

Kısa saylabilecek bir ömre sahip olan Necati Zekeriya sanat hayatına yetişkinlere yönelik şiirle başlamıştır. İlk şiiri, Birlik gazetesinde 1947 yılının Eylül ayında yayımlanmıştır. 1949 yllında 
Makedonya Genç Türk Yazarlarının Eserleri adlı kitapta Necati Zekeriya’nın on dört şiiri vardır. Ortak bir kitap olan bu eserde Şükrü Ramo’nun şiirleri ve Mustafa Karahasan'ın Şaban Hoca adlı tiyatro oyunu da bulunmaktadır. Bu eser aynı zamanda Makedonya Türk edebiyatı açısından da tarihi önemdedir. 1950'de Şiirler adlı kitabı yayımlanır. Bu kitap da yetişkinlere yöneliktir. O günün şartlarında Yugoslavya'daki siyasetin etkisini bu şiirlerde görmek mümkündür. Toplam yirmi bir şiirin yer aldığı bu kitapta Gençliğe Övgü, Darbeciler, Bizdeki Değişikliğe Hayret Edene, Utanacak Onlar, İftiralara, Tito gibi günlük siyasetle doğrudan bağ kuran şiirler bulunmaktadır. Necati Zekeriya 1952 yllında yayımladığı Okul Çanı ile çocuklara yönelik ilk eserini vermiştir. Kısa süreli yaptığı öğretmenliğin de etkisiyle Makedonya'daki diğer öncü Türk sanatçllar gibi o da ilk dönem eserlerini çoğunlukla çocuklar için kaleme almıştır. Kırmızı Küpeler (1952), Silahşör Tavşan (1953) ve Gelincik (1954) bu eserler arasında sayılabilir. Sanatçının diğer isimlerden farkı, edebiyata yetişkinler için başlayıp çocuklar için edebiyatta karar kılmasıdır. Kaya'ya göre (2009: 108) bu ilk şiirlerin konuları çocuk dünyasına çok yakın didaktik ve öğretici niteliktedir. Biraz da günlük ihtiyaçlara ayak uydurarak o yllarda ünlü Yugoslav çocuk yazarlarının etkisi altında yazılmalarına rağmen bu şiirler, edebî nitelikten ve sanat değerinden yoksun değildir. Bu eserler daha sonra bu topraklarda gelişecek, olgunlaşacak çocuk şiirinin temel taşını oluşturmaktadır.

Necati Zekeriya ağırlı̆̆ çocuk edebiyatına verse de yetişkinler için yazmaktan da geri durmamıştır. Şiirler kitabından üç yıl sonra 1953’te Nerde Olsam adlı şiir kitabı yayımlanmıştır. Konu seçimi ve şiir dili bakımından daha olgun bir eser olan bu kitapta ilk kitabın aksine ölçülü ve uyaklı şiirler yer almaktadır. Hatırası henüz taze olan Nazilerin yenilgiye uğratıldığı Halk Kurtuluş Savaşı'nın ve yeni kurulan devletin siyasi etkileri bu kitapta da belirgindir. "Şair Olsam" adlı şiirinde Mehmet Emin Yurdakul'un "Yolcu" şiirinden bir alıntı (Ölümlerden kurtulunur/İleriye gitmekle) dikkati çekmektedir (Yurdakul, 1979: 96). 1954 yılında İlhami Emin ile birlikte Aramak adlı şiir kitabı yayımlanmıştır. Otuz sayfadan oluşan bu küçük hacimli kitaptaki toplam şiir sayısı yirmi sekizdir. İlk on dört şiir Necati Zekeriya'ya, kalan on dört şiir ise İlhami Emin'e aittir. Sanatçının yetişkinleri hedef kitle olarak düşünen diğer kitabı Sevgi başlı̆̆ ile 1965’te yayımlanmıştır. Beş bölümden oluşan bu kitaptaki şiir sayısı otuz beştir. Kitap, şu dizelerle başlamaktadır:

Eğer sözlükten tek bir söz seçmek zorunda kalsaydım

Kuşkusuz bu söz Sevgi olacaktı

Eğer dünya yüzünde Sevgi olmasaydı

Sanırım onu ben bulacaktım (Zekeriya, 1965: 5).

Adından da anlaşılacağı gibi kitaptaki şiirlerin teması sevgidir. Sanatçı, bu şiirler yoluyla kendisi için hayattaki tek anlamlı şeyin sevgi olduğunu ısrarla vurgulamaktadır. 1977 yllında Lorka Soyutlaması adlı yine yetişkin okura yönelik bir kitabı daha yayımlanır. İspanyol bir devrimciden etkilenen Necati Zekeriya, şiir kitabını onun adından esinlenerek vermiştir. Garsiya Lorka adını taşıyan savaşçının hayatından hareketle ona hitaben yazılmış dizelerde yiğitliği, mertliği, özgürlük için yapılan savaşın kutsallı̆ını anlatmaktadır. Otuz beş şiirin bulunduğu bu kitapta şiirlerin ayrı başlıkları yoktur. Sanatçının ölümünden kısa süre sonra 1989'da yayımlanan Çayhane Şiirleri yine yetişkinlere hitap etmekle birlikte konu olarak önceki şiirlerinden oldukça farklıdır. Yetişkinler için eserler kaleme almış olsa da sanatçının asıl verimli olduğu alan çocuk edebiyatıdır. Hem yazar hem şair hem çevirmen hem de yayıncı olarak çocuk edebiyatının birçok farklı alanında çalışmalar yapmıştır. Hatta büyükler için yazdığı eserlerde dahi çocuk ve çocukluk ile ilgili unsurlara rastlanmaktadır. 1987 yllında, Priştine'de çıkan Çevren dergisindeki bir yazısında sanatçı, çocuk edebiyatını nasıl gördüğünü şu cümlelerle açıklamaktadır: 
Necati Zekeriya (children's stories, children's poems and children's literature anthologies) in the context of their contribution to Macedonian Turkish children's literature / M. S. Kıymaz (pp. 242-266)

“Çağdaş çocuk edebiyatı yazarları, çocukları kendilerinden biri olarak bilmeli, kendi yaşamsal sorunlarını, dünya görüşlerini, kıvanç ve acılarını çocuklarla bölüşmekte, onlarla dostça, arkadaşça konuşmalıdırlar. Çocuk da yaşına göre büyük bir insandır ve müthiş ciddidir. Onunla şaka etmeye gelmez, hele onu cinlerle, perilerle, yalan dünyalarla avutmak çok yanlış bir tutumdur.” (Aktaran: Ali, 2008).

Necati Zekeriya’nın çocuk şiirlerinde Fazıl Hüsnü Dağlarca etkisinden söz etmek mümkündür. Ayrıca Kaya (2008)'ya göre onun şiirlerinde zengin bir birikime sahip Yugoslavya çocuk şiirinin etkisi de görülmektedir. İsen (2001: 53)'in ifadesiyle Necati Zekeriya, Makedonya Türk şiirinin büyük ustalarından biri ve çocuk edebiyatının da bir numaralı adıdır. Mahalli etkilerden arınmış canlı bir dil, değişik edebiyatları iyi tanımış ve yer yer onların izlerini hissettirmiş olmasına karşın hep kendine özgü kalan bir deyiş, muhtevaya uygun bir şekil meydana getirmedeki ustalık ve tatlı bir anlatım onun çocuklarla ilgili kitaplarının temel özellikleridir. Leontiç (2011)'in altını çizdiği üzere, Necati Zekeriya'nın barış, özgürlük ve iyilik mesajlarıyla dolu şiirler kaleme almasının altında yatan sebep çocuklukta yaşadığı kötü günleri unutmak ve acıları aşma düşüncesidir. Küȩüklerin büyük şairi (İsen ve İsen, 1983) olarak anılan Necati Zekeriya yer yer ağız özellikleri yansitsa da esas olarak İstanbul Türkçesini benimsemiş ve eserlerinde kullanmıştır. Türkçenin doğru ve kurallı bir şekilde kullanılmasını savunan yazar, gerek yayımladığı çocuk dergilerinde gerekse de edebiyat sanat dergisi Sesler'de bu anlayışa uygun düşen yazılar kaleme almıştır.

Sanatçının işlediği konular çeşitlilik göstermektedir. Bir tarafta çocukluğunun geçtiği Üsküp sokakları ve sosyal çevresi, öte yandan Rumeli kültürüne ait tekerlemeler, türküler eserlerinde sıklıkla yer bulan unsurlardır. Bununla birlikte daha genel olarak, evrensel duygulara da yer vermiştir. Saygı, sevgi, özgürlük, kıymet bilme, çalışkanlık gibi iletilere onun eserlerinde sıklıkla rastlamak mümkündür. Necati Zekeriya, edebiyata yönelik bakış açısını, 1986 yılında Mustafa Ruhi Şirin'e yazdığı bir mektubunda kısa ve öz olarak şu şekilde ifade etmektedir: "Ben, yaşamım boyunca, yazına, estetik-sanat açısından bakmış bir insanım ve inanıyorum ki, değerli bir şiir (bir tek şiir ya da bir tek öykü) bütün ideolojilerden daha uzun ömürlüdür.” (Zekeriya, 1986).

Necati Zekeriya’nın yaşadığı dönem Tito önderliğindeki Yugoslavya dönemidir. Bu anlamda, devlette hâkim olan düşünce yapısına uygun düştüğü varsayılan başta Nazım Hikmet, Orhan Kemal ve Fazıl Hüsnü Dağlarca olmak üzere bazı Türkiyeli sanatçıların Necati Zekeriya'yı etkilediğini söylemek mümkündür. Türkiye'de yayımlanan çeşitli edebiyat dergilerinde de imzasına rastlanan Necati Zekeriya, özellikle Nazım Hikmet (Zekeriya: 1986c) ve Orhan Kemal (Zekeriya, 1971b) hakkında yazılar kalem almıştır. Adı geçen bu sanatçıların biyografilerine ve çeşitli şiirlerine Birlik sayfalarında sıkça rastlamak mümkündür. Onun şiirlerindeki serbest ölçü Nazım Hikmet etkisini akla getirirken, çocuk şiirlerinden bazılarının konusu ise Fazıl Hüsnü Dağlarca'nın tarzı ile oldukça uyuşmaktadır. Türkiye'deki edebiyat çevreleri ile de yakın ilişki içinde olan sanatçı, özellikle Yaşar Nabi Nayır öncülüğünde yayımlanan Varlık dergisine 1967 yllından itibaren gerek kendi hikâye ve şiirlerini gerekse de çevirdiği hikâye ve şiirleri göndermiştir. 1967 yılında çıkan Varlkk dergisinin 703. sayısında yayımlanan şiirinin adı Sevgiden Kalan'dır. Şiir ve hikâye haricinde Necati Zekeriya'nın bazı derleme, çeviri ve inceleme yazılarına da Varlk sayfalarında rastlamak mümkündür.

Ölümünün ardından çıkan bir yazıda (Kaya, 1988) onun Mehmet Emin Yurdakul'dan Nazım Hikmet'e, Blaje Koneski'den Lorca'ya uzanan çeşitli etkilerden beslenen bir şair olduğu anlatılmaktadır. Sanatçının bu etkilenmelerden kurtulup zaman zaman özgün söyleyişler aradığı, özellikle bağlı olduğu hümanist olguyu daha da geliştirip yaşadığı ortamın ideolojisiyle bağdaşmayan, eskimiş, köhneleşmiş kurumlara, geleneklere getirdiği eleştirilerde, bu özgünlüğün ardında koştuğu belirtilmektedir. Necatigil 
(1975)'in adlandırmasına göre Necati Zekeriya Yugoslavya ve Türkiye arasında bir kültür elçisidir. Bu unvanı, o günkü Türk edebiyatını Yugoslavya sınırları içerisindeki Türklere; dönemin çağdaş Yugoslav edebiyatını, özellikle şiirini ise Türkiye'de tanıtmak yoluyla almıştır. On Makedon Ozanı, Çağdaş Yugoslav Şiiri Antolojisi, Struga Akşamları, Çağdaş Makedonya Şiiri, Yugoslav Hikâye Antolojisi gibi seçkiler dışında Radovan Pavlovski'den Göl Ülkesi, Vasko Popa'dan İçimizdeki, İzzet Sarayliç’ten Sunu, Blaje Koneski'den Yıldızları Örmek, Mateya Matevski'den Güzellik Üçgeni gibi eserleri Türkçeye kazandırmıştır.

Necati Zekeriya'nın Türkçe konusundaki hassasiyeti, Makedonya'da yaşayan Türk çocukları için dil bilgisi ve okuma kitapları yazacak kadar ileri düzeydedir. Özellikle Üsküp Ağzı olarak adlandırılabilecek ve üzerince henüz yeterince çalışma yapılmamış olan yöreye has ağız özelliklerinin en azından resmi ortamlarda, okullarda terk edilmesi, Necati Zekeriya'nın başlıca arzularından olmuştur. Eski Yugoslavya içindeki cumhuriyetlerin okullarındaki temel okuma kitapları listeleri (lektür) için Makedonca, Sırpça, Hırvatça, Slovence, Arnavutça ve Macarca dillerinde Türk yazarlardan sadece Necati Zekeriya yer almaktaydı. Onun çocuk edebiyatı sahasındaki başarısı tüm Yugoslavya'da bilinmektedir (Tufan, 1996). Günümüzde Makedonya sınırları içerisindeki Makedonca, Arnavutça ve Türkçe eğitim veren okulların lektür listelerinde de Harfler Ne Yer ve Orhan adlı eserler yer bulmaktadır.

\section{Necati Zekeriya'nın çocuk edebiyatı çalışmaları}

Bu bölümde, Necati Zekeriya'nın asıl uğraş alanı olan çocuk edebiyatı sahasında verdiği emekler ve ortaya koyduğu ürünler derli toplu olarak göz önüne serilmeye çalışlacaktır. Yazara ait kitaplar; Üsküp’teki çeşitli sahaf ve kütüphanelerden, Kiril Metodiy Üniversitesi Türkoloji Bölümü kütüphanesinden, Ankara Milli Kütüphane'den, Türkiye'deki çeşitli kitap koleksiyoncularından ve Çocuk Vakfı kütüphanesinden temin edilmiştir. Sanatçının kitaplarının toplu bir basımı mevcut değildir. Basılan eserleri ise çok eski tarihli oldukları için çeşitli özel kütüphanelerde, koleksiyonerlerde ve Makedonya'nın bazı şehirlerinde yer alan kütüphanelerinde az sayıda bulunmaktadır.

Çocuk edebiyatı Necati Zekeriya'ya göre ciddi bir iştir. O, eski anlayışla yazılmış kitapların bir kenara bırakılması gerektiği; bununla birlikte çizgi roman gibi popüler türlere de sorumlulukla yaklaşılması gerektiğini düşünmektedir. Sanatçının çocuk edebiyatı anlayışı şu cümle ile özetlenebilir: "Çocuğa ciddi olarak, dostça, arkadaşça yanaşmak gerek, ona hocalık etmekten, profesör, öğretmen gibi, daha akıllıymışız gibi davranmaktan sakınmamız gerek.” (Zekeriya, 1989: 274). Sanatçı, çocuk edebiyatına yönelmesinde çocuk dergilerinde editör olarak çalışmasının etkili olduğunu belirtmektedir. Dergilere malzeme bulmak için dünya çocuk edebiyatını, Yugoslav çocuk edebiyatını, Türk çocuk edebiyatını ve Yugoslavya'daki Türkçe çocuk edebiyatını izlemesi gerektiğini vurgulamaktadır (Zekeriya, 1987b). Üç alt başlık halinde yapılandırılan bu bölümde, Necati Zekeriya'nın hazırladığı antolojiler, yazdığı hikâye kitapları ve kaleme aldığı şiir kitapları üzerinde durulmuştur.

\section{1. Çocuk edebiyatı antolojileri}

Necati Zekeriya, çok yönlü bir sanatçı olmasının yanında araştırmacı ve derlemeci kimliği ile de ön plana çıkmaktadır. Özellikle Makedonya edebiyatının Türkiye'de tanıtılması ve buna karşılık olarak Türk sanatçıların Yugoslavya'da bilinirliğinin artmasında onun payı büyüktür. Bununla birlikte Yugoslavya sınırları içinde ürün veren Türk sanatçıları da yayımladığı antolojiler ile tanıtmayı amaçlamıştır. Sanatçı, bu zengin birikimini Türk okullarında okuyan çocuklar için oluşturduğu okuma kitaplarında (Yaprak, Demet, Dal) da kullanmıştır. Tüm bunlardan hariç olmak üzere Yugoslavya sınırları içinde 
Necati Zekeriya (children's stories, children's poems and children's literature anthologies) in the context of their contribution to Macedonian Turkish children's literature / M. S. Kıymaz (pp. 242-266)

bulunan cumhuriyetlerde yaşayan ve farklı diller konuşan sanatçıların eserlerini de kendisi bizzat Türkçeye çevirerek Türk okuyucu ile buluşturmuştur. Bahsedilen bu antolojiler için önsözler kaleme alan Necati Zekeriya'nın çocuk edebiyatına bakışına dair ipuçlarını bu ön sözlerden görmek mümkündür. Çiğdem adlı antolojisinde Zekeriya (1985: 5) kendi açısından antoloji oluşturmanın zorluklarını çocuklara şu cümlelerle açıklamaktadır:

Sevgili çocuklar,

Size bir sırrımı anlatmak istiyorum. Örneğin güldeste (antoloji) nasıl yapılır? Kolay değildir. Hiç de kolay değildir. Diyelim, bahçıvan amca, annelerinizin günü için size izin verse de siz çiçek bahçesine girip annenize bir çiçek demet derleseniz, sanır mısınız ki en güzellerini derlemiş olursunuz. Tüm çiçeklerden birer örnek seçseniz bile, yine bir soru sorulabilir: Acaba o örnek çiçeğinin en güzeli seçilmiş midir? İşte öykü, şiir antolojisi yaparken, bu iş de biraz derlenen çiçek demetine benzer. Ama kusursuz olmayacă̆ını bildiğimiz halde bahçelerden çiçek derleriz, yazınlardan da tıpkı böyle öykü, şiir derleriz antolojiler yaparı.

Necati Zekeriya'nın edebî uğraşı içinde antolojilerin mühim bir yeri vardır. Kendisi antolojiler yayımlamayı, bölgede yeşeren Türk edebiyatını tanıtmak için bir görev olarak düşünmektedir. Sanatçı, hem bu amacını gerçekleştirebilmek bununla birlikte vatandaşı olduğu ülkenin edebiyatını anavatan Türkiye'de tanitabilmek için antolojilerden yararlanma yolunu seçmiştir (Kıymaz, 2019). Necati Zekeriya'nın en önemli yönlerinden biri Şirin (2019)'e göre edebiyat editörlüğüdür. Sanatçının bu yönü, onun hazırladığı antolojiler üzerinde yapılacak araştırmalarla daha belirgin olarak ortaya çıkacaktır. Necati Zekeriya antoloji konusunu çok önemsemektedir. Sanatçının Mustafa Ruhi Şirin’e gönderdiği yayımlanmamış (1986b) mektuplarında, “Antoloji Nasıl Yazılı?” adını taşıyan bir kitap yazmayı planladığı bilgisi yer almaktadır. Kaya (2008) da sanatçının ailesinden aldığı bilgilere dayanarak, yayıma hazır; fakat basılmamış “Güldestelere Meraklı mısınız?" adlı bir kitaptan bahsetmektedir. Sanatçının derleyip düzenlediği, çeşitli tarihlerde basılan on çocuk edebiyatı antolojisi aşă̆ıda yayım tarihlerine göre yer almaktadır. Yayım tarihlerine göre sıralanan bu antolojilerin bazılarının ön sözleri, sanatçının antoloji yaparken göz önünde bulundurduğu hususları ortaya koyması bakımından önemli görülmektedir. Aşă̆ıda, sanatçının düzenlemiş olduğu antolojiler sıralanmakta ve değerlendirilmektedir.

Çiçek adlı antoloji ilk olarak 1959 yılında yayımlanmıştır. Araştırma sonucunda yazarın bu eserinin Sevinç Yayınları tarafından basılan 1969 tarihli ikinci baskısına ulaşılmıştır. Yazar bu kitaba yazdığı ön sözde kitabın ilk yayımlanışının üzerinden on yıl geçtiğini vurgulamakta ve bu süre içinde çocuklar için yazan yeni sanatçıların belirdiğini, onları da seçkiye dâhil ettiğini belirtmektedir. Necati Zekeriya, bu kitabını antoloji olarak nitelememektedir. Ona göre bu kitabın iki amacı vardır. İlki okullarda Türkçe öğrenim gören Türk öğrencilerin kitap ihtiyacını gidermek; ikinci olarak da Birlik gazetesiyle başlayıp Sevinç ce Tomurcuk dergileriyle devam eden bir çocuk edebiyatının varlığını ayak diretmek. Anlaşılacağı üzere, bu seçmede yer alan şiir ve hikâyeler, Birlik, Sevinç ve Tomurcuk süreli yayınlarından derlenmiştir. 1966 yılında bu eserin Arnavutça bir çevirisi yapılmıştır. "Lulet" adını alan bu çeviri Adem Gaytani tarafından yapılmıştır.

Bir Dalda Bin Çiçek-Eski Yugoslavya Halklarmın Şairlerinden Seçmeler adlı kitabın basım tarihi 1964’tür. Koço Raçin Yayınevi tarafından basılan bu kitapta “Bir Dalda Bin Çiçek Nasıl Doğdu?” adlı bir başlık bulunmaktadır. Bu eseri oluşturma fikrinin nasıl geliştiğini anlatan Zekeriya, karşılaştığı zorlukları bu başlık altında anlatmıştır. Bu kitapta Türk çocuk yazar ve şairlerinin eserlerine yer verilmemiştir. Ön söz olarak adlandırılabilecek bu bölümde Necati Zekeriya Yugoslavya'yı oluşturan cumhuriyetlerden birbirine yakın sayıda şair ve şiir almaya gayret ettiğini bildirmekte ve çocuk şiirinden ne anladığını da ortaya koymaktadır. Ona göre (Zekeriya, 1964a) Yugoslavya çocuk şiiri eski didaktik 
anlayışlardan, kötü yanlardan, babalardan, amcalıktan, öğreticilikten, vezindeki kalıplardan, çocuk şiirinin eğlence işi olduğu düşüncelerinden uzak bir şiirdir. Çocuk için yazılan bu nitelikli şiirlerin, iyi şiirin her yaş grubu tarafından okunabileceği gerçeği ışı̆̆ında çocuk büyükleri tarafından da seve seve okunabilecek şiirler olduğu vurgulanmaktadır. Ona göre güzel şiirlerin yediden yetmişe okunabileceği kuralının haklı yanı bu şiirlerde kendini bir kez daha göstermiştir. Bu anlayış devrine göre ilerici bir bakış açısı anlamına gelmektedir. Bu seçkide, 44 şaire ait 96 şiir yer almıştır. Şairlerin isimlerine göre alfabetik bir düzene göre oluşturulan bu seçkide Necati Zekeriya dipnotlar aracıllğı bazı kelimelerin anlamlarını açıklamış, bazı şiirlerin ise hangi kitaptan alındığı bilgisine yer vermiştir. Kitabın kapağı Dimitar Kondovski tarafından çizilmiştir. İçerikteki çizimler ise İvan Velkov'a aittir. Çocuk kitabı resimlemenin ayrı bir uzmanlık dalı olduğunun farkında olan Zekeriya, bilinçli bir çocuk edebiyatçısı olduğunu bu seçkide göstermektedir.

Seçme Masallar adını taşıyan masal seçkisi (Zekeriya, 1964b) Sevinç Yayınları tarafından yayımlanmıştır. Toplam yedi masalın yer aldığı bu seçkide Çizmeli Kedi (Charles Perrault), Parmak Çocuk (Grimm Kardeşler), Küçük Muk (Wilhelm Hauf), Bülbül (Hans Chistian Andersen), Bulut Sakal'la Yüksek Gök'ün Kış Masalı (Zakris Topelius), Mutlu Prens (Oscar Wilde) ve Salkım Söğüt (Eflatun Cem Güney) adlı masallar bulunmaktadır. Masalların çevirmenleri olarak şu isimler yer almaktadır: Ahmet Aşkın, Kemal Kaya, Müşerref Hakimoğlu ve Ülkü Tamer.

İnciler-Nobel Ödülü Kazanan Yazarlardan Seçme Çocuk Öyküleri adlı kitabın ilk baskısı 1966'da yapılmıştır. Bu antoloji, Üsküp'te yayımlanmasından sonra İstanbul'da Milliyet Yayınları tarafından değişik tarihlerde $(1971,1971,1973,1976,1985)$ toplam beş kez Nobelcilerden Çocuk Hikâyeleri adıyla basılmıştır. Necati Zekeriya (1971a), bu antolojide Nobel Edebiyat Ödülü’nü alan 18 yazardan birer hikâyeye yer vermiştir. Bu hikâyelerden önce, hikâyelerin yazarları hakkında kısa biyografik bilgiler bulunmaktadır. Hikâyelerin bazıları Necati Zekeriya tarafından bazıları ise başka Türk çevirmenler tarafından Türkçeye aktarılmıştır. Antolojinin baş kısmında "Nobel Armağanı'nın Kurucusu Alfred Nobel Kimdir?” başlıklı bir bölüm vardır. Bu bölümde Necati Zekeriya, dinamitin icadından başlayarak Alfred Nobel'in doğumu, babası ile ilişkileri, iş hayatındaki başarısızlıkları ve patlayıcı imalatı işinde nasıl büyüdüğünü kronolojik olarak anlatmaktadır. Alfred Nobel'in patlayıcı alanındaki icatlarıyla kitlesel insan ölümlerine sebep olmasının verdiği pişmanlıkla ölümünden bir yıl önce Nobel Ödülleri'nin temeli atması anlatılmaktadır. 1901'den 1971'e kadar olan sürede Nobel Edebiyat Ödülü'nü alan yazarlar listelenmiştir. Necati Zekeriya antolojiye aldığı 18 yazarı hangi ölçüte göre antolojiye aldığına dair herhangi bir bilgi vermemektedir.

Uçun Kuşlar Uçun adlı antoloji bir çocuk hikâyeleri antolojisidir. Necati Zekeriya (1978a), bu kitabı Türkiye'deki çocuk okurlar için hazırlamıştır. 1978 yılında Koza Yayınları tarafından basılan bu kitapta Yugoslavya'ya yaşayan Türk yazarlarının hikâyelerine yer verilmiştir. Bu yazarlar hakkında kısa biyografik bilgilere de onların hikâyelerinden önceki sayfada yer verilmiştir. Bu antolojide hikâyesi bulunan yazarlar şunlardır: Alaaddin Tahir, Enver Baki, Fahri Kaya, Hasan Mercan, Hüseyin Süleyman, İlhami Emin, İskender Muzbeg, Mustafa Karahasan, Necati Zekeriya, Nusret Dişo Ülkü, Süreyya Yusuf ve Şükrü Ramo. Başlarken adlı bölümde Necati Zekeriya Türk çocuklarına seslenmiş ve onlara Yugoslavya'daki Türk çocuklarından, onların okullarından ve çocuk dergilerinden bahsetmiştir.

Buket-Priče i Pjesme Pisaca Turske Narodnosti u Jugoslaviji adlı antoloji (1981a), yazarın Türkçe dışındaki bir dilde oluşturduğu tek seçkidir. Türkçeye Yugoslavya'daki Türk Halkı Yazarlarından Çocuk Şiirleri Öyküleri olarak çevrilebilecek olan bu antoloji, Sarajevo (Saraybosna)'da Lastavica adlı yayınevi tarafından basılmıştır. Necati Zekeriya'nın Makedonya ve Kosova Türk çocuk edebiyatını doğru 
Necati Zekeriya (children's stories, children's poems and children's literature anthologies) in the context of their contribution to Macedonian Turkish children's literature / M. S. Kiymaz (pp. 242-266)

olarak aktarmak amacıyla gösterdiği çeviri hassasiyeti bu seçkide belirgindir. Kitabı Boşnakçaya çeviren Dr. Lamija Hadẓiosnanović iken, hikâye ve şiirleri anlam olarak düzenleyen kişi ise Nasiha KapidzićHadzić'dir. Bu kişi alanında ödülleri olan Bosnalı bir çocuk edebiyatı yazarıdır. Kapaktaki resim ve içerikteki çizimler ünlü Boşnak karikatürist Hasan Fazlić imzasını taşımaktadır. Kitabın içerinde 21 farklı Türk şair ve yazardan metinler yer almaktadır. Hikâye-şiir karışık olarak düzenlenen bu seçkide Hüseyin Süleyman, Recep Murat, Enver Tuzcu, Şükrü Ramo, Mustafa Karahasan, Süreyya Yusuf, Necati Zekeriya, Fahri Kaya, İlhami Emin, Naim Şaban, Nusret Dişo Ülkü, Nimetullah Hafız, Enver Baki, Arif Bozacı, Hasan Mercan, İskender Muzbeg, Bayram İbrahim, Avni Abdullah, Alaettin Tahir Suat Engüllü ve Agim Rıfat'ın metinlerine yer verilmiştir. Kitabın sonunda, seçkide yer alan sanatçların kısa biyografileri de bulunmaktadır. Bir ön söz olarak düşünülen Zašto Buket (Neden Buket?) başlığı altında Necati Zekeriya Boşnak çocuklara seslenmektedir. Onlara Makedonya ve Kosova'daki Türk çocuklarını tanıtmaktadır. Türk çocukların okullarından, Sevinç, Tomurcuk, Kuş gibi çocuk dergilerinden ve onlar için yazan yazarların varlığından söz etmektedir. Necati Zekeriya'ya göre antolojiye ismini veren Buket, çok farklı çiçeklerden oluşan rengârenk bir bahçeyi sembolize etmektedir. Ona göre çocuklar için yazan Türk yazarlarının eserleri de bir bukete benzetilebilir. Bu buketin içinde tıpkı farklı çiçekler gibi hikâye, masal, roman, şiir ve tiyatro oyunları gibi farklı türlerde edeb(î) metinler bulunmaktadır. Necati Zekeriya Boşnak çocuklara şöyle hitap etmektedir: "Size sunduğumuz tüm bu masallar, hikâyeler ve şiirlerin içinde çocukların üzüntüleri, mutlulukları, oyunları, dilekleri, umutları, duyguları yani iyi ve asil olan her şey daha mutlu bir geleceği gösteriyor. Sevgili çocuklar size bu buketi gülümseyerek sunuyorum. Seveceğinizi umarak en sevdiğiniz çiçeği seçmeniz umuduyla.” (Zekeriya, 1981: 5).

Aslen Makedonya'nın İştip şehrinden olan Kemal Karatekin'in sahibi olduğu Tekin Yayınevi 1982 yılında Necati Zekeriya'nın Demet (Seçme Çocuk Öyküleri) adını taşıyan seçkisini yayımlamıştır. Bu seçkinin baş kısmında "Küçük Dostlarımıza" hitabıyla başlayan bir ön söz vardır. Burada Necati Zekeriya Türkiye'deki çocuklara seslenmektedir. Makedonya ve Kosova'da yaşayan Türk çocuklarının dergilerinden bahseden Zekeriya, Türkiyeli birçok yazarın Makedonya ve Kosova'daki Türk çocukları tarafından okunduğunu belirtir. “Acaba siz Yugoslavya'da yaşayan, Türkçe yazan değerli yapitlar yaratan Türk yazarlarını tanıyor musunuz?” (Zekeriya, 1982: 7) diyerek bu seçkiyi oluşturmaya Kemal Karatekin ile birlikte nasıl karar verdiklerini anlatmaktadır. Seçkide on üç yazardan toplam on sekiz hikâye yer almaktadır. Seçkide hikâyesi yer alan yazarlar şunlardır: Hüseyin Süleyman, Şükrü Ramo, Mustafa Karahasan, Süreyya Yusuf, Necati Zekeriya, Fahri Kaya, Recep Murat, Nusret Dişo Ülkü, Enver Baki, Hasan Mercan, İskender Muzbeğ, Avni Abdullah ve Alaettin Tahir.

Necati Zekeriya'nın Çiğdem-Çocuk Şiirimizin Güldestesi adlı antolojisi onun ömrünün sonlarına doğru yayımladığı antolojilerdendir. Kitabın ön sözünde Yugoslav Türk Çocuk Şiiri hakkında başlangıcından gelişimine doğru uzanan çizgide bazı önemli bilgiler verilmektedir (Zekeriya, 1985). On altı şairden toplam doksan sekiz şiir bulunan bu antolojide, şairlerin kısa hayatları hakkında kısa birer bilgi ve çocuklar için yazdıkları şiir kitaplarının isimleri ile yayım tarihleri yer almaktadır. Necati Zekeriya, çoğunu şahsen tanıdığı bu şairleri, onların şiirlerini doğum tarihlerine göre sıralamıştır. Ön söz bölümünde, şairlerin çocuklara hangi açılardan yaklaştıklarını ve hangi konuları öncelediklerini de belirtmiştir. Bununla birlikte, yine ön söz kısmında şairler kendi aralarında dönemsel olarak da ayrılmıştır. Bu antolojide şiirlerine yer verilen şairler şu isimlerden oluşmaktadır: Enver Tuzcu, Şükrü Ramo, Necati Zekeriya, Fahri Kaya, İlhami Emin, Naim Şaban, Nusret Dişo Ülkü, Nimetullah Hafız, Arif Bozacı, Hasan Mercan, Bayram İbrahim, İskender Muzbeg, Avni Engüllü, Suat Engüllü, Agim Rifat Yeşeren ve Zeynel Beksaç. 
Necati Zekeriya, Yugoslav Yazarlarından Çocuk Öyküleri (Zekeriya, 1988a) adını taşıyan öykü seçkisini oluşturmak için uzun ylllar beklemiştir. Gerek sağlık sorunları, gerekse de işleri sebebiyle sürekli ertelediği bu kitabı, Türkiye'den Tarık Dursun K. ve Doğan Hızlan gibi isimlerin de teşvik etmesi ve Birlik Yayınları'nın basmaya karar vermesiyle 1988 yılında yayımlamıştır. Seçkiyi oluşturan öykülerin kaynağı, yaklaşık yirmi yıl Necati Zekeriya tarafından yönetilen ve Üsküp’te basılan Sevinç ve Tomurcuk çocuk dergileridir. Yönettiği bu dergilerde çocukların diğer kültürlere ait yazarları da tanımasına büyük önem veren sanatçı, bu hikâyeleri ileride yayımlamak üzere dosyalamıştır. Toplam altmış sekiz hikâyenin yer adlığı bu seçkide Türk, Boşnak, Sırp, Hırvat, Karadağlı, Sloven, Makedon, Arnavut, Macar, Rusin, Romen, İtalyan, Slovak ve Bulgar yazarlardan öyküler bulunmaktadır.

Sevgiyle (Çocuk Öykümüz Güldestesi), (Zekeriya, 1988b) Tan Yayınları tarafından Priştine'de basılmıştır. 200 sayfadan oluşmaktadır. Bu seçkide Necati Zekeriya Yugoslavya sınırları içerisinde yaşayan Türk yazarların öykülerini derlemiştir. Seçkiye alınan kimi yazarlar öykülerini kitaplaştırmıştır. Kimi yazarların hikâyeleri ise Sevinç, Tomurcuk, Kuş gibi çocuk dergilerinin sayfalarında kalmıştır. Necati Zekeriya bu seçkiyi oluştururken hem öykü kitaplarından, hem de çocuk dergilerindeki öykülerden seçmeler yapmıştır. Kitabın ön sözünde seçkinin ortaya çıkış sürecini anlatan sanatçı, dört alt başlık altında başlangıcından itibaren Yugoslavya Türk öykücülüğünün geçtiği aşamaları ve sanatçılar bağlamında eserleri anlatmaktadır. İşledikleri konulara göre öykü yazarlarını sınıflayan ve bazı kısa bilgiler veren Necati Zekeriya, antoloji yapmanın zorluklarına da değinmektedir. Bu seçkide yirmi farklı yazara ait toplam elli sekiz öykü yer almaktadır.

\section{2. Çocuklar için hikâye kitapları}

Necati Zekeriya, yazdığı kısa hikâyelerle tüm Balkanlarda tanınan bir çocuk yazarıdır. Orhan adlı karakterin başından geçen maceralar etrafında şekillenen bu hikâyeler başta Makedonca ve Sirphırvatça olmak üzere birçok Balkan diline çevrilmiştir. Özgün bir karakter olan Orhan, Türk bir çocuk olmasına rağmen, yaşadığı sokakta diğer milletlerin mensupları da yaşamaktadır. Orhan'ın arkadaşları arasında Makedon, Arnavut ve Çingene çocuklar da vardır. Bu sebepledir ki Orhan'ın maceralarını ele alan bu kısa hikâyeler, lektür listesi denilen ve Türkiye'deki 100 Temel Eser benzeri listelere de girmiş, gerek zorunlu gerekse de seçmeli şartı ile Makedonya sınırlarında eğitim öğretim yapan okullarda günümüzde dahi okutulmaktadır.

Yazarın 1961 yılında yayımladığı ilk hikâye kitabı Bizim Sokağın Çocukları adını taşımaktadır. Otuz beş hikâyenin yer aldığı bu kitaptaki ilk metin kitaba da isim olmuştur. Kitaptaki tüm hikâyelerde kahraman Orhan'dır. Necati Zekeriya'nın kısa hikâye alanında oluşturduğu eserler içinde en çok bilineni Bizim Sokağın Çocukları'dır. Daha sonra yayımlanan hiçbir hikâye kitabı bu ilk kitabın eriştiği seviyeye erişememiş hep bu eserin gölgesinde kalmıştır. Bu kitaptaki hikâyeler oldukça kısa olmalarına rağmen iletiler güçlü bir şekilde verilmektedir. Yazarın ustalığı bu hikâyelerde belirgindir. Özellikle kolay okunabilir olmaları ile bu metinler çocuklar tarafından çok sevilmiştir. Necati Zekeriya'nın diğer ülke edebiyatları ve eleştirmenleri tarafından da tanınmasındaki esas rol bu kitaptadır. Betimlemelerin yer almadığı bu hikâyelerde karşılıkı konuşmalar önemli yer tutmaktadır. Bu kitap Türkiye'de de farklı yıllarda (1968, 1979, 1991, 2006, 2018) farklı yayınevlerince (Varlık, Cem, Kök, Uçan At) tekrar basılmıştır.

Yeni Sokağın Çocukları (1967a) adlı ikinci hikâye kitabı, ilk hikâye kitabından beş yıl sonra yayımlanmıştır. Aynı kahraman Orhan üzerinden anlatılan hikâyelerde yazar zaman zaman öğüt verici bir tarz da uygulamıştır. Kitaptaki ilk hikâye yazarın belleğinde önemli yer eden 1963 Üsküp Depremi 
Necati Zekeriya (children's stories, children's poems and children's literature anthologies) in the context of their contribution to Macedonian Turkish children's literature / M. S. Kiymaz (pp. 242-266)

hakkındadır. 27 hikâye arasında “Bir Fiço’nun Beş Küçük Öyküsü” adlı diğerlerine göre uzun bir hikâye de vardır. Bu metinde yazar kimliğini de açık etmekte ve kendini Orhan’ın şair-yazar babası olarak okuyucuya tanıtmaktadır.

Eski Sokağın Çocukları (1967b) kitabında kendi hayatını anlatan Necati Zekeriya, düşünülmüş Orhan’ı savaş yllarında incelemekte, savaşa katılmayıp da kentte kalan ama savaşın bütün acılarını yaşayan bir çocukluğu, bir eski sokağın çocuklarının hayatını anlatmaktadır (Zekeriya, 1967: 69). Bu kitabın yayın tarihi Bizim Sokağın Çocukları kitabından sonra olsa da içerikteki hikâyeler Necati Zekeriya'nın yazdığı ilk çocuk hikâyeleridir. On dört hikâyeden oluşan kitabın kapağını ve çizimlerini Dimitar Kondovski yapmıştır. Bu hikâyeler ilk olarak Birlik Gazetesi'nin Çocuklara sayfasında ve Sevinç çocuk dergisinde yayımlanmıştır. Bu kitaptaki metinler kendine has bir özellik göstermektedir. Diğer hikâyelerde olmayan bir şekilde yazar bu hikâyelerde kahramanları ve olayların geçtiği yerleri tanıtma eğilimindedir. Necati Zekeriya'nın hayatından bahseden yukarıdaki bölümlerde anlatılan zorluklar bu kitapta somutlaştırılmaktadır. Nazi ve Bulgar işgali altındaki Üsküp’te yaşayan çocukların bakış açısıyla zorluklar ve anlamsız hale gelen çocukluk çağı gözler önüne serilmektedir. Sanatçının diğer hikâye kitaplarında Orhan esas kahramanken bu kitapta Orhan'ın yanında diğer çocukların yaşadıkları da odaktadır. Sanatçı, bu eserin kendisi için önemini şu cümlelerle ifade etmektedir:

\begin{abstract}
"Ben aslında çocukluğumu Eski Sokağın Çocukları adlı kitabımda anlatmaya çalıştım. Bu kitabım Türkiye'de henüz yayımlanmadı. Bu kitabımda da başkahraman Orhan'dır ama Orhan savaş yıllarında (1941-45 yıllarında) başından geçen olayları anlatmaktadır. Orhan çalgı çalınan, türkü yakılan bir ailede büyürken, bol bol gülerken bir gün evinde büyüklerini kederli görür ve o gün ilk kez "savaş" sözünün çok korkunç bir şey olduğunu anlar. Dört yıl evlerinde çalgı çalınmaz, türkü söylenmez.” (Zekeriya, 1987: 364).
\end{abstract}

Sanatçının dördüncü hikâye kitabı Güzel Nedir Çirkin Nedir? başlığı altında 1968'de yayımlanmıştır. Bu kitaba kaynaklık eden hikâyeler ilk olarak 1967 yılında Makedonca-Türkçe olarak yayımlanan KüçükBüyük Çocuklar adlı kitapta yer almaktadır. Bahsedilen bu kitaptaki hikâyeleri Makedoncaya İlhami Emin çevirmiştir. Daha sonra 1968 yılında Güzel Nedir Çirkin Nedir? Adıyla Türkçe-Makedonca olarak tekrar basılmıştır. 1970 yılında ise aynı kitap sadece Türkçe olarak Türkiye'de Varlık yayınları tarafından yayımlanmıştır. Kitabı resimleyen Dimitar Kondovski'dir. Varlık baskısında başlangıç ve bitiş başlıkları hariç toplam kırk iki hikâye yer almaktadır. Bu hikâyelerden bir kısmı eski kitaplardan alınmadır. Kitapta Orhan karakteri önceki kitaplara göre bazı farklılıklar gösterir. Yalan, hile, hırsızlık, kaba konuşmalar gibi istenmeyen davranışlar gösteren Orhan yaş olarak da farklı görünümler göstermektedir. Bu kitapta ayırıcı bir özellik olarak şiir formundaki hikâyeler göze çarpmaktadır. Hatta Necati Zekeriya'nın şiir kitaplarından oluşan Damlalar adlı seçkide Güzel Nedir Çirkin Nedir? kitabından, şiire yakın olduğu için sekiz metin alınmıştır.

Bizim Sokağın Romeo ve Julieti (1978) adlı beşinci kitapta esas kahraman yine Orhan'dır. İngiliz yazar William Shekespeare'a ait bir eserden hareketle isim verilen bu kitapta Orhan'a eşlik eden Sevil adlı bir karakter daha vardır. İlkokul dördüncü sınıfa giden Orhan ve Sevil aynı mahallede, aynı apartmanda oturmakta ve aynı okulun aynı sınıfında eğitim almaktadır. Hikâyelerde anlatılan olaylar bu kez sokağın dışındadır. Bir okul yılı boyunca anlatılan tüm olaylar okulda geçer. Birbirlerinden hoşlanan iki çocuğun yaşadıklarını temeler alan hikâyelerde yer yer küçük çocuklardan beklenmeyecek davranışlar ve seviye üstü tavırlar görülmektedir. Yirmi beş hikâyeden oluşan bu kitapta Orhan ve Sevil'e bazı çocuklar da eşlik etmektedir. Kürdan Fıçı, Şişko gibi isimler ikinci plandadır.

Eskiler Alırım Yeniler Satarım (1981b) adlı kitap, sanatçının altıncı ve yayımlanmış son hikâye kitabıdır. Toplam 48 hikâyenin yer aldığı bu kitap Necati Zekeriya'nın Priştina yıllarında yayımlanmıştır. Yazarın 
büyük ilgiyle karşılanan diğer hikâye kitaplarının aksine bu kitap içeriği dolayısıyla sönük kalmıştır. Orhan ve Sevil bu kitapta da görülmektedir; fakat Sevil’in etkisi azalmıştır. Diğer yardımcı kahramanlara ek olarak bu kitapta konunun ilerlemesinde ve okuyucunun ilgisini canlı tutmada önemli katkısı olan Eskici adlı bir karakter vardır. Hatta kitabın adı bile bu kahramandan hareketle konulmuştur. Bu kitaptaki Orhan'ın kaç yaşında olduğu net değildir. Toplama bir görünüm arz eden hikâyelerde konular okur ilgisini canlı tutmaktan yer yer uzaklaşmaktadır. Diğer hikâyelerde olduğu gibi diyaloğun önemli yer tuttuğu bu metinlerde farklı olan yazarın okuyucuya yönelttiği sorulardır.

Yukarıda anılan altı hikâye kitabı, Necati Zekeriya tarafından yayımlanan kitaplardır. Yazarın bu hikâyeleri çocuklar tarafından okunup benimsendikçe bu altı hikâye kitabının zaman içerisinde tekrar baskıları yapılmıştır. Tekrar baskı haricinde bu kitaplardan çeşitli birleştirmeler ve seçmeler yoluyla yeni kitaplar da oluşturulmuştur. Necati Zekeriya'nın Orhan karakteri temelinde yazdığı üç hikâye kitabının birleştirilmesiyle ortaya çıkan üçleme, Orhan (1988c) adı altında, yazarın öldüğü yıl Üsküp’te basılmıştır. Bu kitap içerik olarak onun üç hikâye kitabının (Bizim Sokağın Çocukları, Yeni Sokağın Çocukları ve Bizim Sokağın Romeo ve Jülieti) bir arada basılmış halidir. Koza Yayınları da 1979 yllında aynı kitabı Türkiye'de basmıştır. Türkiye'de Necati Zekeriya imzası ile yayımlanan Hikâyeler (1996) adlı kitabın içeriği de Orhan adlı kitap ile aynıdır. MEB, ilerleyen yıllarda Hikâyeler (1999) başlıklı kitabı ikinci defa basmıştır. Yakın tarihte Üsküp’te basılan Orhan (2017) adlı kitap da yukarıda bahsi geçen kitaplarla aynı içeriğe sahiptir. Necati Zekeriya'nın hikâyelerinden oluşan bir diğer kitap ise Sırpça yayımlanan Djeca Stare Ulice adlı kitaptır. Üç Sokağın Çocukları olarak Türkçeye çevrilebilecek bu kitapta Dreja Națe Ulice (Bizim Sokağın Çocukları) Dreja Nove Ulice (Yeni Sokağın Çocukları) ve Dreja Stare Ulice (Eski Sokağın Çocukları) adlı üç bölüm vardır. Bu üç bölümde toplam kırk adet hikâye yer almaktadır. Bu kitabın diğerlerinden farkı, bir seçki olmasıdır. Ayrıca kitapta Bizim Sokağın Romeo ve Jülieti adlı kitabın yerine Eski Sokağın Çocukları kitabına yer verilmiştir. Bununla birlikte, seçilen kitaplardaki hikâyelerin tamamına yer verilmeyip sadece bir kısmı kapsam dâhiline alınmıştır. Uçan At Yayınları tarafından Çocuk Vakfı desteği ile Mustafa Ruhi Şirin editörlüğünde yayımlanan Çocuk Edebiyatı dizisi içinde Necati Zekeriya’nın üç hikâye kitabı Türkiye'de tekrar yayımlanmıştır. Bunlar sırası ile Bizim Sokağın Çocukları, Yeni Sokağın Çocukları ve Bizim Sokağın Romeo ve Julieti'dir.

Necati Zekeriya'nın çocuk edebiyatına armağanı olan Orhan karakteri, yazarın çocuk bakışına olan hâkimiyetinin bir göstergesidir. Orhan tipi orijinal bir kahraman olarak dikkat çekmektedir. (İsen ve Durmuş, 2008). Çocuklar arasındaki ilişkilere de sık sık hikâyelerinde yer veren yazar, hem kendi çocukluğunu yansıtmakta hem de çocuklara dair iyi bir gözlemci olduğunu yazdığı metinler aracılığı ile göstermektedir. Bununla birlikte yaramaz bir çocuğun anne babası ve diğer akrabalarıyla olan çocuksu halleri ve öğretmeni ile kurduğu bağ da bu hikâyeler aracıllğı ile okura gösterilmektedir. Gürel (2014: 813)' e göre Necati Zekeriya, içinde bulunduğu şartlarla baş ederek kişisel gelişimini tamamlamasına rehberlik ettiği çocuğa Orhan tiplemesi ile yapıcı, barışçı bir gelişim seyri çizmiştir. Çocuk okurlarını kaçmaya değil; içinde bulunduğu şartları irdeleyip çözümler üretmeye yöneltmektedir.

Orhan karakterinin nasıl ortaya çıktı̆̆ını Priştine'de çıkan Tan gazetesine verdiği bir röportajda anlatan sanatçı, Viktor Hugo'nun Sefiller romanındaki Gavroş adlı çocuk karakterinden öykündüğünü anlatmaktadır. Gavroş’un bir yiğitlik simgesi olmasından hareketle romanı çocuklar için bilinir kıldığını vurgulamaktadır. Yazar bu durumu kendi cümleleriyle şu şekilde ifade etmektedir:

Yiğitlik simgesidir Gavroș. Buna bir prototip aradım. 1941 yılı, 6 Nisan'da, Üsküp bombardıman edildiği gün, yitirdiğim ilkokul arkadaşım Orhan’ı çok yıllar sonra anımsadım, öykülerime onu kahraman edindim. O gün bugün çocukların kaygılarını, kıvançlarını onun kişiliğinde kümeleştirmeye çalışırım hep (Beksaç, 1980). 
Necati Zekeriya (children's stories, children's poems and children's literature anthologies) in the context of their contribution to Macedonian Turkish children's literature / M. S. Kiymaz (pp. 242-266)

Bir üçleme olarak yayımlanan ve çocuklar tarafından okunmaya devam eden bu hikâyeler Balkanlar'da birçok dile çevrilmiştir. Hikâyelerde, Necati Zekeriya'nın çocuk edebiyatı anlayışına uygun olarak, satır aralarında çok uluslu bir toplumun ortak yaşama başarısına dair iletiler de bulunmaktadır. Her toplumun kendi dilinde eğitim hakkına dair "Üç Arkadaş" adlı hikâyede çocuklar için ortak dilin sevgi olduğu vurgulanmaktadır. Sanatçının hikâyelerinde ön plana çıkan iletilerden biri de farklı etnik kökenden gelmenin bir öneminin olmadığı ile ilgilidir. Sanatçının çocuk edebiyatına armağanı olan Orhan adlı kahramanın maceraları, Bediha Begovska tarafından tiyatroya uyarlanmıştır. Orhan adını taşıyan bu oyun Üsküp Halklar Tiyatrosu Türk Dramı ekibi tarafından sahneye konulmuş ve çocukların büyük beğenisini kazanmıştır (Kaya, 2008).

Bir dergi için kaleme aldığı "Yugoslavya'daki Türkçe Çocuk Dergilerinde ve Okul Betiklerinde Nasrettin Hoca'nın Fıkraları” başlıklı yazısında dile getirdiği görüşler, onun hikâyelerindeki bazı iletileri daha anlaşılır hale getirmektedir.

Yugoslavya, ulus ve halkların harman yeridir. Bu ülkede beş ulus, on beş halk, birkaç etnik grup yaşar, ayrı ayrı konuşur ama aynı biçimde gülerler. Ulusal sorun bilinçle hallolduğu için her öğrenci kendi ana dilinde öğrenim görür. Değişik dil kullanır ama Nasrettin’in fikralarını aynı özellikle benimserler, doğruyu bulmakta onu bayraklaştırırlar (Zekeriya, 1978: 6).

Necati Zekeriya, yine çocukların ortak paydalarını önceleyerek Küçük Kıpti Kızı hikâyesinde yapılan yanlış davranışları Orhan üzerinden doğru hale getirir. Özellikle hikâyelerin kahramanı Orhan üzerinden değişen ve farklılaşan bir çocukluğun görünümü bu ve benzeri metinler üzerinden takip edilebilmektedir. Anılan bu yönüyle Orhan üçlemesi çocuk edebiyatı açısından da önemli bir noktada konumlanmaktadır. Necati Zekeriya'nın çocuk hikâyeleri hakkında Ali (2008: 14) şu tespitlerde bulunmaktadır:

"Onun hikâyelerinde göze çarpan önemli özellik, çocuk eğitimiyle ilgili öğretici konulardır. Çocuk
psikolojisini çok iyi bilen yazar, çocuklara karşı hiçbir zaman sert bir tavırla yaklaşmaz. Hikâyelerinde
sert bir baba, anne ve öğretmen görülmez. O çocuklara, çocuk düşlerine, çocuk anlayışlarına, çocuk
isteklerine bel bağlamayı bilir."

Sanatçı, Mustafa İsen'e 1983'te verdiği bir röportajda, (İsen, 2009: 194) yukarıda sayılan hikâye kitaplarından başka, Bitişikteki Sokağın Çocukları adlı eserini de tamamladığını belirtmektedir. Maalesef yazarın ömrü bu kitabı yayımlamaya yetmemiştir. Ayrıca, Kaya (2008) Bir Avuç Öykü (Parmak Öyküler) adlı 26 hikâyeden oluşan ve yine Orhan’ı anlatan yayımlanmamış bir kitaptan bahsetmektedir.

\section{3. Çocuklar için şiir kitapları}

Necati Zekeriya'nın sanatında şiir her ne kadar daha önce yazılmışsa da bilinirlik açısından hikâyeden sonra gelmektedir. Çocuğu hedef kitle olarak düşünen ve onun algılama seviyesine uygun eserler verme çabası içinde olan sanatçı, gerek kendi yazdığı gerekse de Yugoslavya sınırları içerinde yer alan ünlü çocuk şairlerinden yaptığı çeviri şiirleri ile bilinmektedir. Yugoslavya içinde de ortaya koyduğu eserler ve gösterdiği çaba takdir edilmiş ve devrin en büyük çocuk edebiyatı ödülü olan Zmay ödülüne layık görülmüştür.

Necati Zekeriya'nın çocuklar için ortaya koyduğu ilk kitabı Okul Çanı'dır. 1952'de Üsküp’te yayımlanan bu kitap 32 sayfadır. Bazı sayfaları resimlerle süslü bu kitaptaki şiirlerin konuları çocukların çevrelerinde gördükleri nesne ve kişilerle ilgilidir. Devrin yöneticisi Tito hakkında övücü bir şiirin de yer aldığı bu kitaba adını veren şiir şu şekildedir:

\footnotetext{
Adres | Address 


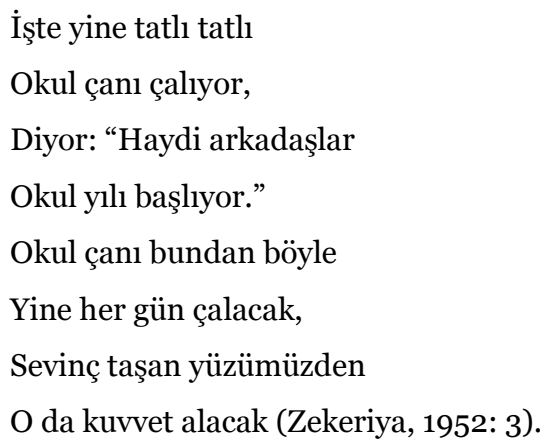

Necati Zekeriya çocuklar için yazdığı bu ilk eserinde okuduğu fabllardan etkilenmiştir. Onu etkileyen yazarlar arasında Beydeba, Topelius, Ezop, La Fonten, Krilov, Dositey Obradoviç, Gustav Kırleç sayılabilir. Sanatçı bu ilk eserini çocukları güldürürken düşündürmek için yazdığını ifade etmektedir (Zekeriya, 1987).

32 sayfadan oluşan Silahşör Tavşan (1953) kitabı Necati Zekeriya’nın çocuklar için yazdığı ikinci şiir kitabıdır. On altı şiir bulunan bu kitapta, ormanda yaşayan çeşitli hayvanlar canlandırma yolu ile günlük hayattaki halleri çerçevesinde anlatılmaktadır. Kitaba adını veren Silahşör Tavşan şiiri şu dizelerle başlamaktadır:

Ben kimim?..

Ben silahşör tavşanım,

Avcıların karşısında

Kükriyen bir aslanım. (Zekeriya, 1953: 3)

Bu şiir dışında, ormandaki hayvanları tanıtan ve yer yer onları konuşturan şiirler yer almaktadır. Kitabın sonunda bir adada evlenen fil çiftinin kırk gün süren düğ̈nünü anlatan uzun bir şiir bulunmaktadır. Bu kitap hakkında Karahasan (1955) Birlik gazetesi sayfalarında bir eleştiri yazısı yayımlamıştır. Karahasan’a göre bu eser, çocuk edebiyatı kitabı olarak kabul edilemez, çocukların edebiyata, güzelliğe, müzik ve resme susamış gözlerini doyuramaz. Bu eleştiri, dönemin zengin edebiyat ortamını göstermesi açısından önemlidir.

Necati Zekeriya'nın çocuklar için yazdığı üçüncü şiir kitabı Gelincik (1954) adını taşımaktadır. Şair, bu eserini öğretmenlik yaptığı dönemde öğrencisi olan çocuklara ithaf etmiştir. "Bu eserimi vaktiyle bende okuyan öğrencilerime ithaf ediyorum” (Zekeriya, 1954: 2) cümlesiyle başlayan kitapta toplam yirmi beş şiir bulunmaktadır. Kitaba ismini de veren ilk şiir "Gelincik" adını taşımaktadır. "ilkbaharda" ve "Sonbaharda" adlı iki bölümden oluşan bu şiirde tarlalarda, çayırlarda sıkça görülen bu çiçek anlatılmaktadır.

Necati Zekeriya'nın çocuklar için yazdığı şiirleri arasında ilk dönem eserleri arasında sayılan kitaplarından sonuncusu Kırmızı Küpeler (1958) adını taşımaktadır. Bu isim kitaptaki şiirlerden birinden gelmektedir. L. Ocaklıevski tarafından çizimleri yapılan bu kitapta otuz iki şiir bulunmaktadır. Genel olarak çocuklarından afacanlıklarından bahsedilen bu kitapta, çocukların oyunları, hayata bakışlarındaki masumiyet ve onların aile bireyleri ile çevreleriyle olan ilişkileri konu edilmektedir. Söz gelimi kitaba adını veren "Kırmızı Küpeler" adlı şiirde özellikle kız çocukları tarafından çok sevilen bir yaz meyvesi olan kiraz konu edilmektedir.

Haydi koşun küpeler

\footnotetext{
Adres Address 
Necati Zekeriya (children's stories, children's poems and children's literature anthologies) in the context of their contribution to Macedonian Turkish children's literature / M. S. Kiymaz (pp. 242-266)

\author{
getirdi şen haziran \\ "Küpelerim kırmızı" \\ odur diye bağıran \\ Küpeleri gerçekten \\ çok beğendim-kırmızı \\ bilmem var mı bir çocuk \\ ki ne sevmez kirazı?..
}

Hele kızlar can verir

kulağına taksınlar,

sonra geçip aynada

güzeller mi baksınlar (Zekeriya, 1958: 38).

İlk olarak 1964 yılında basılan Ninniler 1973 yılında tekrar basılmıştır. Bazı şiirler yeni baskıda yer almazken başka yeni şiirler de bu baskıya eklenmiştir. Yirmi dört şiirin yer aldığı kitabın arka kapağında çocuklara şöyle seslenilmiştir: "Yediden yetmişe dek okunacak bu şiirleri beğeneceksiniz. Çünkü bu şiirlerde sizi çevreleyen acunlar ve düşler var. Kitapta yer alan şiirler birbirine çok benziyorlarsa da her şiir kendi başına bir bütündür." Yayımlandığı dönemde bu şiir kitabı ayrıca beşinci sınıf öğrencileri için yardımcı ders kitabı olarak lektür listesine alınmıştır. Kitabın ismine bakıldığında klasik ninni formunda şiir metinleri ile karşılaşılacağı zannedilse de kitaptaki şiirler serbest ölçü uygulanarak yazılan ve konu olarak özgün olan şiirlerdir. Bu şiirler bir annenin çocuğu için iyi dileklerini, çocukluğunu hatırlayan ve her şeyi yerli yerinde bulan bir yetişkini, rüzgâr ile çocukların oynadığı oyunlar gibi yer yer hayalle karışık konuları işlemektedir (Kıymaz, 2019).

Damlalar (1967c) Necati Zekeriya'nın şiirlerinden oluşan bir seçkidir. Kitabın son bölümünde Damlalar kitabının Necati Zekeriya'nın basılan çocuk şiirleri kitaplarından yapılmış bir derleme olduğu ayrıca belirtilmektedir. O zamana kadar basılan bütün kitapların baskılarının tükendiği anlatılmakta ve çoğu şiirin okullarda öğrencilere okutulması mecbur olan lektür listelerinde yer aldığı vurgulanmaktadır. $\mathrm{Bu}$ kitap aracılığı ile küçük okurların Necati Zekeriya'yı ve onun şiirlerini toplu olarak tanımış, sevmiş olmaları beklenmektedir (Zekeriya, 1967: 91). Antolojiyi oluşturan şiirlerin alındığı kitaplar şunlardır: Okul Çanı, Silahşör Tavşan, Gelincik, Kırmızı Küpeler, Ninniler, Harflerin Türküleri, Küçük-Büyük Çocuklar.

Yeşil Nerde adlı eser Türkçe-Makedonca olarak 1975’te yayımlanmıştır. Bir çocuğun annesine soruları şeklinde düşünülen bu kitaptaki şiirler, çocuk dünyasına ait temiz, saf ve filtresiz bakış açısını gösterme açısından oldukça başarılıdır. Şair hassasiyetini yoğun olarak bu kitaptaki şiirlerine aktaran Necati Zekeriya aynı zamanda çocuğun çevresindeki birtakım nesneleri de dolaylı yolla tanıtmaktadır. Necati Zekeriya'nın Yeşil Nerde adlı şiir kitabında kullandığı soru kalıbına Türkiye'de çocuk şiirinin önde gelen ismi Fazıl Hüsnü Dağlarca'nın Çocuk ve Allah kitabında da rastlanmaktadır. Türkçe ve Makedonca hazırlanan kitabında Necati Zekeriya, çocuk masumiyetiyle annesine sorular soran bir çocuğun ağzından kaleme almıştır şiirlerini. Tüm şiirler bir soru ve devamında sorunun ayrıntılandırılması şeklinde tasarlanmıştır.

Anneciğim

neden mum ışır etrafi? 
yanar kendisi?

Eriyince mum ağlamaz mı çocukları?

ışıksız kalınca

kitap nasll okurlar

nasıl yazarlar ev ödevlerini?

Anneciğim

neden mum ışır etrafi

yanar kendisi? (Zekeriya, 1975: 24).

Bu tarzı anımsatan şiir örneğinde ise Fazıl Hüsnü Dağlarca, yine benzer şekilde bir çocuğun yaşının gelişim özelliğine uygun olarak canlandırma yapması ve annesine seslenmesini aktarmaktadır.

Üfleme bana anneciğim korkuyorum

Dua edip edip, geceleri.

Hastayım, ama ne kadar güzel

Gidiyor yüzer gibi, vücudumun bir yeri.

Anneciğim büyüyorum ben şimdi,

Büyüyor göllerde kamış.

Fakat değnekten atım nerde

Kardeşim su versin ona, susamış. (Dağlarca, 2015: 13).

Dağlarca'nın Çocuk ve Allah kitabını 1940’ta yayımladığı göz önünde bulundurulursa Necati Zekeriya'nın çocuğun annesine seslenmesi şeklinde oluşan bu tarzı Dağlarca'dan esinlenerek oluşturduğu ihtimali akla gelmektedir.

Necati Zekeriya'nın hayattayken yayımladığı son şïr kitaplarından biri de Ağaçlar Dile Gelse (1986a) adını taşımaktadır. Priştine'de yayımlanan bu kitapta sanatçı, ağaçlar başta olmak üzere farklı bitki ve çiçekleri şiir yoluyla tanıtmaya çalışmaktadır. Elif Ayiter tarafından resimlenen bu kitapta toplam kırk bir şiir yer almaktadır. Ağaçlar adlı şiirle başlayan kitapta Çınar, Kavak, Akkavak, Salkımsöğüt, Akasya, Çam, Selvi, Kayın gibi birçok şiir yer almaktadır. Bu kitap Fazıl Hüsnü Dağlarca'nın çocuk dünyasına yakın kimi bitkileri konu alan Bitkiler Okulu adlı kitabını akla getirmektedir. Necati Zekeriya da Fazıl Hüsnü Dağlarca gibi eserlerinde çocuğu özne olarak ele almaktadır. İki sanatçı arasında eserleri yoluyla bir bağlantıdan söz edilebilir. Fazıl Hüsnü Dağlarca'nın ilk çocuk şiirleri kitabı Açıl Susam Açıl'ın 1967 yılında Üsküp’te yayımlanması da bu savı güçlendirmektedir.

Necati Zekeriya'nın okula yeni başlayıp okuma yazma öğrenmeye çalışan çocuklara yardımcı olması amacıyla hazırladığı bir eseri vardır. Harfler Ne Yer? (1987a) adını taşıyan bu eserde, çocuklara şiir formu kullanılarak, tek tek her harf ile ilgili ve o harfle başlayan kavramları anlatan bölümler vardır. Necati Zekeriya bu alfabe kitabını hazırlarken tekerlemelerden, söz oyunlarından, benzetmelerden, türkü sözlerinden, farklı halk edebiyatı ürünlerinden ve coğrafi yerlerden yararlanarak anlatımı kuvvetlendirmeye çalışmıştır. Hatta yer yer hikâyelerindeki kahraman olan Orhan'dan da bahsederek anlatımı somutlaştırmaya ve eğlenceli bir tarzda harfleri öğretme çabası içinde olmuştur. Bu kitabın içeriğini oluşturan şiirler ilk olarak 1966-1967 yıllarında Tomurcuk çocuk dergisi sayılarında Harflerin 
Necati Zekeriya (children's stories, children's poems and children's literature anthologies) in the context of their contribution to Macedonian Turkish children's literature / M. S. Kiymaz (pp. 242-266)

Türküleri başlı̆̆ı altında yayımlanmıştır. Dergi sayfalarında daha uzun olarak tanıtılan harfler, bu kitapta kısaltmalara uğramıştır.

İkinci Dünya Savaşı’ndan itibaren Makedonya topraklarında başlayan Türkçe eğitime bir katkı olarak düşünülen bu eser, yeni baskılarıyla günümüzde de çocuklar tarafından okunmaktadır. Devletin resmi alfabesinin dışında Latin harfleri ile eğitim öğretime ve basım yayın faaliyetlerine devam eden Türk azınlık açısından bu eser 29 harfli Yeni Türk Alfabesini esas alması açısından dikkat çekicidir. Eserde Harflere Türkü başlıklı bir giriş ve 29 harf için ayrı ayrı bölümler vardır. Söz gelimi L harfi için şu mısralar yazılmıştır.

L harfi lambadır,/Işık verir her yere./L harfi laledir/Koku verir evlere./L harfiyle leylek uçar:

"Leylek leylek havada/Yumurtası tavada!"/L harfiyle lokum yeriz/L harfiyle leblebi yeriz.

L harfiyle her şey daha lezzetlidir (Zekeriya, 1987: 20).

Ablama Sevda Şiirleri (1995), Necati Zekeriya'nın ölümünden sonra yayımlanan bir şiir kitabıdır. Bu eserde, Necati Zekeriya'nın dışardan bakan bir bakış açısıyla bir çocuğun ağzından onun ablası ile ilgili konuları eğlenceli bir dille dile getirdiği görülmektedir. Birlik Yayınları tarafından basılan bu şiir kitabında numaralanmış halde başlıksız kırk şiir bulunmaktadır. Yirmi dört numaralı şiir hariç her şiir "Oysa ablam henüz on bir yaşında" dizesiyle bitmektedir. Bu kitap Necati Zekeriya'nın çocuk şiirleri arasında ayrı bir yere sahiptir. Sanatçının ölümünden beş yıl sonra yayımlanan bu kitaptaki şiirler özellikle ilk gençlik çağındaki çocukların kolaylıkla okuyabilecekleri bir tarzda yazılmıştır. Gerek kelime seçimi gerekse de şiirsellik olarak başarılı bir çalışma olan bu kitaptaki şiirlerde, sanatçının hikâyelerinden tanınan Orhan karakteri ile ona âşık olan on bir yaşındaki kız konu edilmektedir.

Yukarıda sıralanan Türkçe çocuk şiirlerinin yanında Necati Zekeriya'nın (1986d) Makedonca yayımlanan ve henüz Türkçeye çevrilmemiş bir çocuk şiiri kitabı daha vardır. Tuka Ziveat Pesni (Burada Şiir Okunur) adlı bu şiir kitabında üç bölüm bulunmaktadır. İlk bölümde aile üyelerine (Annem, Babam, Kız kardeşim, Babaannem, Dedem, Halam, Amcam, Teyzem, Dayım) adanmış şiirler bulunmaktadır. İkinci bölümde meslekler, icracıları (Terzi Süleyman, Çömlekçi Nuri) yoluyla anlatılmaktadır. Son bölümde ise müzik aletlerinden (Davul, zurna, gitar, keman, piyano) bahsedilmektedir. Sanatçının olgunluk dönemine ait bu eserin Türkçeye kazandırılması, üzerine inceleme yapılmasını kolaylaştıracaktır. Uçan At Yayınları tarafından Çocuk Vakfı desteği ile Mustafa Ruhi Şirin editörlüğünde yayımlanan Çocuk Edebiyatı dizisi içinde Necati Zekeriya'nın şiir kitaplarında yer alan şiirlerden bir seçki olarak düşünülen Anne Sevgisi Nedir? başlıkı bir kitap yayımlanmıştır. Kitabın adı Necati Zekeriya'nın aynı isimli bir şiirinden hareketle verilmiştir. Necati Zekeriya'nın kendisinin yayımladığı bu isimde bir kitabı yoktur.

\section{Sonuç ve öneriler}

2. Dünya Savaşı yıllarında çocukluk günlerini okuldan, eğitimden uzak bir şekilde korku ve endişe ile geçiren Necati Zekeriya, savaş sonrası Türkçe öğretmenlik kurslarına giderek eğitimini devam ettirmiştir. İlk şiiri ve devamında ilk kitabının yayımlanması da bu yıllara rastlar. Sanatçının çocukları bu denli önemsemesi ve onlara Türkçe kitaplar yazması, onun ana dili Türkçe öğretimine verdiği değeri göstermektedir.

Devlet işleyişinde kullanılan Kiril Alfabesi’nin yerine Atatürk tarafından Türkiye'de kullanımı başlatılan "Yeni Türk Alfabesi"nin Makedonya Türkleri tarafından kabul edilmesi, anayurt ile yakınlaşma çabası 
olarak değerlendirilmektedir. Eserlerini bu yeni alfabe ile kaleme alan Necati Zekeriya, İstanbul Türkçesini benimsemiştir. Onun eserlerinde yerel söyleyişlere ve ă̆ız özelliklerini gösteren örneklere çok az rastlanır. Necati Zekeriya'nın dil ile ilgili görüşlerini Sesler ve Çevren dergilerinde görmek mümkündür. Henüz toplu olarak değerlendirilmeyen bu yazılarda başta toplumun aydınları olmak üzere tiyatro sanatçllarının, gazetecilerin, başka dillerden Türkçeye çeviri yapan insanların ve son olarak da özellikle okullardaki öğretmen ve öğrencilerin Türkçeyi doğru ve etkili kullanmaları üzerinde durulmaktadır.

Türkiye'de çıan dergiler ve edebiyat çevreleri Necati Zekeriya'nın eserlerine ve sanatına yeterli ilgiyi göstermemişlerdir. Onun ünü daha çok Balkan ülkeleriyle sınırlı kalmıştır. 1944’ten itibaren Üsküp merkezli olarak kendini yeniden Türkçe ifade etme şansı bulan Türk toplumunun diğer önemli düşünür ve yazarları da Necati Zekeriya'nın anılan dönemden günümüze uzanan çizgideki yerini tasdik etmektedirler. Ne var ki Necati Zekeriya'nın eserlerinin bugüne kadar tam koleksiyonunu basan ya da ele alıp inceleyen bir çabaya rastlanılmamaktadır. Bu durumun sebeplerinden biri Necati Zekeriya'nın devrin Yugoslav idarecileri ile iyi geçinmesi ve bu şekilde Türkçe yazma imkânı bulmuş olması olabilir. Türk topluluğu açısından özellikle Yücelcilerin acı akıbeti ile birlikte Yugoslav idaresine ve onunla işbirliği yaptığını düşündükleri kişilere karşı bir hoşnutsuzluk oluşması kuvvetle muhtemel ve doğaldır. Gelinen noktada Yugoslav devleti dağılmıştır.

Necati Zekeriya'nın eserlerinin ve biyografisinin tam ve eksiksiz olarak yayımlanması hem Makedonya Türk edebiyatı hem de Türkiye'deki Türk edebiyatı açısından çok önemlidir. Üsküp’te bulunan Yeni Balkan Yayınları, Necati Zekeriya'nın Orhan, Harfler Ne Yer? ve Bizim Sokağın Çocukları adlı eserlerini yeniden basmıştır. Takdir edilmesi gereken bu çabanın daha sistematik ve sanatçının tüm eserlerini kapsayan bir anlayışla devam etmesi beklenmektedir. Bununla birlikte 60 yll boyunca devam eden ve konuyla ilgili insanlar tarafından "Makedonya Türklerinin Okulu" olarak adlandırılan Birlik gazetesinin yıllara göre ciltlenmiş koleksiyonu depolarda çürümeye terk edilmiştir. Araştırmacıların daha kolay ulaşabilecekleri bir şekilde günümüz teknolojik imkânları kullanılarak bu arşivin zamanın yıpratıcı etkilerinden kurtarılması gerekmektedir. Böylesi bir çaba, hem adı geçen gazetede bir müddet de başyazarlık yapan Necati Zekeriya'nın saklı kalan tüm eserlerine ulaşma imkânı sağlayacak hem de Makedonya Türkçe çocuk edebiyatının tüm yönleri ile ortaya çıkmasına yardımcı olacaktır.

Günümüzde Üsküp’te Türkler tarafından kurulan ve Türk kültürünü yaşattığını iddia eden birçok dernek bulunmaktadır. Çayırlı (2015) bu derneklerin sayısını 118 olarak vermektedir. Bu derneklerden bazıları değişik vesilelerle Türkiye Cumhuriyeti tarafından desteklenmektedir. Necati Zekeriya'yı yakından tanıyan Kaya'nın (2008) onun ailesiyle yaptığı görüşmelere dayanarak aktardığına göre yazarın yayımlanmaya hazır ve dosyalar halinde de birçok eseri bulunmaktadır. Ayrıca Necati Zekeriya ölmeden önce kendi yazdığı yazıları ve farklı yazar ve şairlerle yaptı̆̆ı söyleşileri de titizlikle dosyalamıştır. Yukarıda anılan dernekler, öncelikle Necati Zekeriya gibi değeri henüz layı̆̆ıyla anlaşılamamış sanatçıları ve eserlerini gün ışığına çıkararak tanıtmalıdır.

Geçmiş yıllarda bazı çalışmalarda (Gürel: 2012) Necati Zekeriya'nın eserlerinin 100 Temel eser listelerine alınarak Türk çocukları tarafından okunmasının sağlanması gibi önerilerde bulunulmuştur. Günümüzde 100 Temel Eser Uygulaması yürürlükten kaldırılmıştır. Bununla birlikte yine MEB eliyle gerçekleştirilebilecek daha etkili bir yolla Necati Zekeriya'nın Türk çocuklarına tanıtılması mümkündür. Türkçe Dersi Öğretim Programı (2019: 18) içerisinde yer alan "Ders Kitaplarına Alınacak Metinlerin Nitelikleri” başlıklı bölümde yer alan ilk madde, bu kitapları hazırlayanlara Balkan Türklerine ait edebî eserleri kullanmalarını bir zorunluluk olarak sunmaktadır. Çocuk edebiyatı alanında zengin bir eser 
listesine sahip olan sanatçı, bu yolla Türkiye'deki Türk çocuk okurlar tarafından okunabilir. Necati Zekeriya'nın yaptığı faaliyetler toplu olarak düşünüldüğünde, onun çocuk edebiyatı özelinde Türk dilini ve kültürünü yaşatmak, yaymak ve yeni kuşaklara aktarmak konusunda ne denli yorulmaz bir çaba içinde olduğu anlaşlacaktır. Bugün görece daha iyi ekonomik ve sosyal şartlara sahip Makedonya Türk toplumunun yeni nesilleri, Türkiye'den aldıkları büyük maddi ve manevi desteğe rağmen, Necati Zekeriya'nın ortaya koyduğu gerek yazınsal gerekse de araştırmacı çabanın uzağındadırlar.

\section{Kaynaklar}

Ağanoğlu, H. Y. (2017). Osmanl'dan Cumhuriyet'e Balkanların Makûs Talihi: Göç. İstanbul: İz.

Ali, F. (1995). "Makedonya Çocuk Edebiyatı”. Birinci Çocuk Edebiyatı Sempozyumu (içinde). Haz: Zeki Gürel, Ankara: İlesam.

Ali, M. (2008). "Makedonya Türklerinin Edebiyatında Çocuk Hikâyeleri (Giriş)”. Makedonya'da Türk Edebiyatı-Çocuklara Bir Tutam Hikâye. Manastır: Nid Mikena.

Beksaç, Z. (1980). "Her Yönüyle Yazıncılarımız Yazın Sofrasında-En Eski Ama En Zor Zanaat Sevmektir". Tan Gazetesi, 1980.

Beksaç, Z. (2014). Balkanlarda Türk Çocuk Edebiyatı. Türk Dili Dergisi Çocuk ve İlk Gençlik Edebiyatı Özel Sayısı (içinde). Cilt: CVII Sayı: 756, Editör: Mustafa Ruhi Şirin. Ankara: TDK.

Çayırlı, N. (2015). “Makedonya Türk Kimliği Bağlamında Makedonya'daki Türk Sivil Toplum Kuruluşları”. AVRASYA ETÜDLERİ 48/2015-2 (143-188).

Çelebi, T. (2015). Makedonya Türk Çocuk Edebiyatının İlk Gazetesi: Pioner (İnceleme-Fihrist). TÜRÜK Uluslararası Dil, Edebiyat ve Halk Bilimi Araştırmaları Dergisi Yıl: 3 Sayı: 6 Sayfa: 119-139.

Dağlarca, F. H. (2015). Çocuk ve Allah. İstanbul: YKY.

Füruzan. (2018). Balkan Yolcusu. İstanbul: YKY.

Gürel, N. R. ve Gürel Z. (2010). Fahri Kaya Hayatı-Sanatı-Eserleri. Ankara: Berikan.

Gürel N. R. (2014). Necati Zekeriya ve Samet Behrengi’nin Eserlerinde Müstakbel Vatandaş Olarak Çocuk. Türk Dili Dergisi Çocuk ve İlk Gençlik Edebiyatı Özel Sayısı (içinde). Cilt: CVII Sayı: 756, Editör: Mustafa Ruhi Şirin. Ankara: TDK.

Gürel, N. R. ve Gürel Z. (2015). Orhan. Üsküp: Yeni Balkan.

Gürel, N. R. (2017). Kırmızı Gülün Adı Var. Üsküp: Yeni Balkan.

Hamzaoğlu, Y. (2010). Balkan Türklüğ̈̈ (Makedonya, Hrrvatistan, Osmanl Öncesi Balkan Müslümanh ğı) Cilt I. Üsküp: Logos-A.

Hasan, H. (1998a). Makedonya'da Türkçe Eğitim ve Abdulhakim Hikmet Doğan. Üsküp: Birlik.

Hasan, H. (1998b). Makedonya Türk Çocuk Edebiyatının İlk Eseri. Güneydoğu Avrupa Araştırmaları Dergisi. Cilt: o, Sayı: 12, ss: 117-123.

Hayber, A. (2001). Makedonya ve Kosova Türklerinin Edebiyatı. İstanbul: MEB.

Hayber, A. (2008). Makedonya Türklerinin Edebiyatı ve Çocuk Şiiri (Giriş). Makedonya'da Türk Edebiyatt-Çocuklara Bir Demet Şiir. Manastır: Nid Mikena.

İsen, M. (1997). Türkiye Dışındaki Türk Edebiyatları Antolojisi 7: Makedonya Yugoslavya (Kosova) Türk Edebiyatt. Ankara: Kültür Bakanlığı.

İsen, M. (2001). Balkanlarda Türk Çocuk Şiiri. bilig, Türk Dünyası Sosyal Bilimler Dergisi. Sayı:18/Yaz. İsen, M., İsen R. ve Kireççi A. E. (2008). Balkanlarda Türk Çocuk Şiiri Antolojisi. İstanbul: Varlık. İsen, M. (2009). Varayım Gideyim Urumeline. İstanbul: Kapı.

İsen, M. (2013). "Zekeriya, Necati” (1928-1988). TDV İslam Ansiklopedisi C. 44. İstanbul: Türkiye Diyanet Vakfi Yay. 209-210. 
İsen, R. ve İsen M. (1983). Yugoslavya Türk Çocuk Şïrlerinden Seçmeler. Ankara: Kültür ve Turizm Bakanlığı.

İslam, A. (2001). Balkanlarda Türkçe Basın Hakkında Bir Değerlendirme. bilig, Türk Dünyası Sosyal Bilimler Dergisi Sayı:19/Güz.

K. Tarık Dursun (1992). “Ben Unutmadan-Necati Zekeriya Ihlamurlar Kâşifi”. Varlı. Sayı: 1018. 35-36.

Karahasan, M. (1955). "Silahşör Tavşan Şiirleri Çocuk Edebiyatı ve Sanattan Uzak”. Birlik Gazetesi, S. 262.

Karahasan, M. (1995). Eleştiriler. Üsküp: Birlik.

Kaya, F. (Tarihsiz). Şafak Sökerken. Üsküp: Yeni Balkan.

Kaya, F. (1994). Seçme Yazılar. Üsküp: Birlik.

Kaya, F. (1999). “Makedonya'da Türkçe Yayın Hayatı” Balkan Ülkelerinde Türkçe Eğitim ve Yayın Hayatı Bilgi Şöleni (2O-24 Nisan 1998) Bildiriler (içinde). ss: 251-281. Ankara: TDK.

Kaya, F. (2008). Makedonya Türklerinden İz Bırakanlar. Üsküp: Divan.

Kaya, F. (2008). "Edebiyatımızda Dram Türü (Giriş)”. Makedonya'da Türk Edebiyatı-Bir Deste Oyun. Manastır: Nid Mikena.

Kaya, F. (2009). Gün Bugün. Üsküp: Yeni Balkan.

Kaya, G. (1988). "Şair Ağabey: Necati Zekeriya”. Hürriyet Gösteri Sanat Edebiyat Dergisi. Eylül 1988, S. 94

Kıymaz, M. S. (2019). Balkanlar'da Türkçenin Sesi Necati Zekeriya ve Onun Makedonya'da Antolojiler Yoluyla Türkçeyi Yaşatma Çabası. Uluslararası Türkoloji Araştırmaları Sempozyumu Tam Metin Kitabl. (UTAS, 26-28 Eylül 2019-Van) e-ISBN: 978-975-7616-70-2. 211-218.

Kıymaz, M. S. (2019). Balkanlarda Türk Çocuk Edebiyatının Sembol İsmi Necati Zekeriya'nın Ninniler Adlı Kitabı Üzerine Bir Araştırma. 6. Uluslararası Çocuk ve Gençlik Edebiyatı Sempozyumu Bildirileri. (18-19 Ekim 2019 Bakü) ISBN: 978-605-67557-8-1 232-244.

Leontiç, M. (2011). Necati Zekeriya’nın Şiirlerinde Çocuk Sevgisi. Bal-Tam Türklük Bilgisi, Sayı 14, ISSN: 1452-2179.

Mercan, H. (2002). Balkanlar'da Çağdaş Türk Çocuk Edebiyatı Antolojisi. Ankara: Başbakanlık BasınYayın Enformasyon Genel Müdürlüğü.

Necatigil, B. (1975). Edebiyatımızda İsimler Sözlüğü. İstanbul: Varlık.

Neydim, N. (1998). Çocuk ve Edebiyat. İstanbul: Bu.

Özcan, R. (2015). Bir Başka Tepeden Üsküp. Ankara: Kurgan Edebiyat.

Taşgetiren, A. (1984). Necati Zekeriya Yugoslavya Türk Edebiyatını Anlatıyor. Türk Edebiyatı, S. 123, SS.19-21.

Tufan, M. (1996). Makedonya Türk Edebiyatına Damgasını Vuran Şair. Türk Dünyası Dil ve Edebiyat Dergisi. Sayı: 1, ss: 130-133.

Tufan, M. (1998). Makedonya Arnavutları ve Türkleri “Case Study”: Gostivar. Güneydoğu Avrupa Araştırmaları Dergisi. Cengiz Orhunlu Özel Sayısı. 363-393.

Turan, Ö. (1996). “Makedonya'da Türk Varlı̆̆ı ve Kültürü”. bilig, Türk Dünyası Sosyal Bilimler Dergisi Sayı: 3/Güz.

Şirin, M. R. (2019). Balkanlarda Türkçenin Çağdaş Çocuk Edebiyatçısı: Necati Zekeriya-Günlük. (1982-2019 Arası Tarihleri Kapsayan Yayımlanmamış Günlükler).

Yurdakul, M. E. (1979). Türk Sazı. İstanbul: Atlas.

Zekeriya, N. (1952). Okul Çanı. Üsküp: Destka Radost.

Zekeriya, N. (1953). Silahşor Tavşan. Üsküp: Destka Radost. 
Zekeriya, N. (1954). Gelincik. Üsküp: Koço Raçin.

Zekeriya, N. (1958). Kırmızı Küpeler. Üsküp: Destka Radost.

Zekeriya, N. (1961). Bizim Sokağın Çocukları. Üsküp: Kultura.

Zekeriya, N. (1964a). Bir Dalda Bin Çiçek. Üsküp: Koço Raçin.

Zekeriya, N. (1964b). Seçme Masallar. Üsküp: Sevinç.

Zekeriya, N. (1964c). Ninniler. Üsküp: Kultura.

Zekeriya, N. (1967a). Yeni Sokağın Çocukları. Üsküp: Makedonska Kniga.

Zekeriya, N. (1967b). Eski Sokağın Çocukları. Üsküp: Nova Makedonya Yayımevi-Destka Radost.

Zekeriya, N. (1967c). Damlalar. Üsküp: Nova Makedonya Yayımevi-Destka Radost.

Zekeriya, N. (1968). Güzel Nedir Çirkin Nedir. Üsküp: Kultura.

Zekeriya, N. (1969). Çiçek (Çocuk Edebiyatımızdan Seçmeler). Üsküp: Sevinç.

Zekeriya, N. (1971a). Nobel'cilerden Çocuk Hikâyeleri. İstanbul: Milliyet.

Zekeriya, N. (1971b). “Orhan Kemal'e Sevgi Övgü”. Yeni Ufuklar. C. 19 Ocak 1971, S. 224. ss: 44-47.

Zekeriya, N. (1973). Ninniler. Üsküp: Sevinç Kitapları.

Zekeriya, N. (1975). Yeşil Nerde. Üsküp: Destka Radost.

Zekeriya, N. (1978a). Uçun Kuşlar Uçun. İstanbul: Koza.

Zekeriya, N. (1978b). Bizim Sokağın Romeo ve Jülieti. Priştine: Tan.

Zekeriya, N. (1978c). Yugoslavya'daki Türkçe Çocuk Dergilerinde ve Okul Betiklerinde Nasrettin Hoca'nın Fikraları. Ilgaz Dergisi. Yıl: 17, Sayı: 202.

Zekeriya, N. (1981a). Buket. Sarajevo: Lastavica.

Zekeriya, N. (1981b). Eskiler Alrım Yeniler Satarım. Priştine: Tan.

Zekeriya, N. (1982). Demet (Seçme Çocuk Öyküleri). İstanbul: Tekin.

Zekeriya, N. (1985). Çiğdem. Priştine: Tan.

Zekeriya, N. (1986a). Ağaçlar Dile Gelse. Priştine: Tan.

Zekeriya, Necati (1986b). Mustafa Ruhi Şirin’e Yazdığı Yayımlanmamış Mektup.

Zekeriya, N. (1986c). Nazım Hikmet-Mayakovski. Yaba Öykü, Eylül-Ekim 1986, Sayı: 12, ss: 5-8.

Zekeriya, N. (1986d). Tuka Ziveat Pesni. Üsküp: Destka Radost.

Zekeriya, N. (1987a). Harfler Ne Yer. Üsküp: Birlik.

Zekeriya, N. (1987b). "Necati Zekeriya'yla Yugoslavya'da Türkçe Çocuk Edebiyatı Üzerine.” Çocuk Edebiyatı Yıllı̆̆ı (içinde). Editör: Mustafa Ruhi Şirin. İstanbul: Gökyüzü.

Zekeriya, N. (1988a). Yugoslavya Yazarlarmdan Çocuk Öyküleri. Üsküp: Birlik.

Zekeriya, N. (1988b). Sevgiyle. Priştine: Tan.

Zekeriya, N. (1988c). Orhan. Üsküp: Birlik.

Zekeriya, N. (1989). "Necati Zekeriya ile Yugoslavya'da Yayınlanan Türkçe Çocuk Dergileri Üzerine". Çocuk Edebiyatı Yıllığı (içinde). Editör: Mustafa Ruhi Şirin. İstanbul: Gökyüzü.

Zekeriya, N. (1995). Ablama Sevda Şïrleri. Üsküp: Birlik.

Zekeriya, N. (2018). Anne Sevgisi Nedir? İstanbul: Uçan At.

Zekeriya, N. (2019). Mustafa Ruhi Şirin'e Yazdığı Yayımlanmamış Mektupları. 